\title{
Investigation of the sources and processing of organic aerosol over the Central Mexican Plateau from aircraft measurements during MILAGRO
}

\author{
P. F. DeCarlo ${ }^{1,2, *}$, I. M. Ulbrich ${ }^{1,3}$, J. Crounse ${ }^{4}$, B. de Foy ${ }^{5}$, E. J. Dunlea ${ }^{1}$, A. C. Aiken ${ }^{1,3, * *}$, D. Knapp ${ }^{6}$, \\ A. J. Weinheimer ${ }^{6}$, T. Campos $^{6}$, P. O. Wennberg ${ }^{4}$, and J. L. Jimenez ${ }^{1,3}$ \\ ${ }^{1}$ Cooperative Institute for Research in Environmental Sciences (CIRES), University of Colorado, Boulder, CO, USA \\ ${ }^{2}$ Department of Atmospheric and Oceanic Science, University of Colorado, Boulder, CO, USA \\ ${ }^{3}$ Department of Chemistry and Biochemistry, University of Colorado, Boulder, CO, USA \\ ${ }^{4}$ California Institute of Technology, Pasadena, CA, USA \\ ${ }^{5}$ Department of Earth and Atmospheric Sciences, Saint Louis University, St. Louis, MO, USA \\ ${ }^{6}$ National Center for Atmospheric Research, Boulder, CO, USA \\ *now at: Laboratory of Atmospheric Chemistry, Paul Scherrer Institut, Switzerland \\ ** now at: Institute of Atmosphere and Climate, ETHZ, Switzerland
}

Received: 14 January 2010 - Published in Atmos. Chem. Phys. Discuss.: 2 February 2010

Revised: 20 May 2010 - Accepted: 8 June 2010 - Published: 15 June 2010

\begin{abstract}
Organic aerosol (OA) represents approximately half of the submicron aerosol in Mexico City and the Central Mexican Plateau. This study uses the high time resolution measurements performed onboard the NCAR/NSF C130 aircraft during the MILAGRO/MIRAGE-Mex field campaign in March 2006 to investigate the sources and chemical processing of the OA in this region. An examination of the $\mathrm{OA} / \triangle \mathrm{CO}$ ratio evolution as a function of photochemical age shows distinct behavior in the presence or absence of substantial open biomass burning (BB) influence, with the latter being consistent with other studies in polluted areas. In addition, we present results from Positive Matrix Factorization (PMF) analysis of 12-s High-Resolution Timeof-Flight Aerosol Mass Spectrometer (HR-ToF-AMS) OA spectra. Four components were resolved. Three of the components contain substantial organic oxygen and are termed semivolatile oxygenated OA (SV-OOA), low-volatility OOA (LV-OOA), and biomass burning OA (BBOA). A reduced "hydrocarbon-like OA" (HOA) component is also resolved. LV-OOA is highly oxygenated (atomic $\mathrm{O} / \mathrm{C} \sim 1$ ) and is aged organic aerosol linked to regional airmasses, with likely contributions from pollution, biomass burning, and other sources. SV-OOA is strongly correlated with ammonium ni-
\end{abstract}

Correspondence to: J. L. Jimenez (jose.jimenez@colorado.edu) trate, $\mathrm{O}_{\mathrm{x}}$, and the Mexico City Basin. We interpret SV-OOA as secondary OA which is nearly all ( $>90 \%)$ anthropogenic in origin. In the absence of biomass burning it represents the largest fraction of OA over the Mexico City basin, consistent with other studies in this region. BBOA is identified as arising from biomass burning sources due to a strong correlation with $\mathrm{HCN}$, and the elevated contribution of the ion $\mathrm{C}_{2} \mathrm{H}_{4} \mathrm{O}_{2}^{+}(\mathrm{m} / \mathrm{z}, 60$, a marker for levoglucosan and other primary BB species). WRF-FLEXPART calculated fire impact factors (FIF) show good correlation with BBOA mass concentrations within the basin, but show location offsets in the far field due to model transport errors. This component is small or absent when forest fires are suppressed by precipitation. Since PMF factors represent organic species grouped by chemical similarity, additional postprocessing is needed to more directly apportion OA amounts to sources, which is done here based on correlations to different tracers. The postprocessed AMS results are similar to those from an independent source apportionment based on multiple linear regression with gas-phase tracers. During a flight with very high forest fire intensity near the basin $\mathrm{OA}$ arising from open $\mathrm{BB}$ represents $\sim 66 \%$ of the OA mass in the basin and contributes similarly to OA mass in the outflow. Aging and SOA formation of $\mathrm{BB}$ emissions is estimated to add $\mathrm{OA}$ mass equivalent to about $\sim 32-42 \%$ of the primary BBOA over several hours to a day. 


\section{Introduction}

The MILAGRO campaign took place during March 2006 and was designed as a comprehensive study to characterize the emissions and chemical transformations from a tropical megacity (Molina et al., 2010). Results from this campaign have shown that approximately half of the submicron aerosol mass is composed of organic species (referred to as "organic aerosols", OA) (DeCarlo et al., 2008; Kleinman et al., 2008; Aiken et al., 2009b) consistent with results from previous winter/spring campaigns in Mexico City (Chow et al., 2002; Vega et al., 2004; Salcedo et al., 2006; Molina et al., 2007).

Since OA is a major component of submicron aerosols, it is important to determine their sources in Mexico City. OA source apportionment (SA-OA) is an active area of research where many uncertainties remain. A commonly applied SAOA technique is chemical mass balance of organic molecular markers (CMB-OMM) (Schauer et al., 1996). In the last 5 years SA-OA based on factor analysis of Aerodyne AMS mass spectra has become established as an alternative source apportionment technique. The AMS-based technique is less chemically specific, but has the advantages of (a) very high time resolution, and (b) apportionment based on chemical patterns of the whole OA mass, rather than only based on tracers that contribute minimally to OA mass. Zhang et al. (2005a) developed a Custom Principle Components Analysis (CPCA) method to separate organic aerosol into hydrocarbon-like organic aerosol (HOA) and oxygenated organic aerosol (OOA), which is typically interpreted a surrogate for secondary OA (SOA). Zhang et al. (2007) reported results at multiple worldwide locations using a Multiple Component Analysis (MCA) method and showed that OOA was the largest component, even in urban areas, and became overwhelmingly dominant at rural and remote locations. Positive Matrix Factorization (PMF) (Paatero and Tapper, 1994; Paatero, 1997) has also been applied to AMS datasets, typically identifying two types of OOA and sometimes additional primary OA sources (Lanz et al., 2007; Lanz et al., 2008; Nemitz et al., 2008; Allan et al., 2010; Jimenez et al., 2009; Lanz et al., 2009; Ng et al., 2010; Ulbrich et al., 2009). Results from PMF-AMS have been compared with four other techniques to determine the POA/SOA split (Zhang et al., 2005b; Takegawa et al., 2006; Docherty et al., 2008) and with the CMB-OMM method at two locations (Docherty et al., 2008; Aiken et al., 2009b), with overall good agreement.

Several methods of source apportionment of OA (or of fine PM in some cases) during MILAGRO have been applied, with generally consistent results but also with some differences. A study by Stone et al. (2008) concluded that $49 \%$ of the organic carbon (OC) in the city was due to motor vehicle emissions while $32 \%$ of the OC on the periphery was attributed to this source. Aiken et al. (2009b) estimated that urban combustion sources, including motor vehicles but also other sources such as meat cooking, contributed $29 \%$ to the total OA concentrations at the T0 supersite. Aiken et al. (2009b) also identified a local, presumably industrial, OA source that contributed $9 \%$ of the OA at T0.

Rapid and intense secondary OA (SOA) formation (from chemical reactions of gas-phase species) from urban emissions in Mexico City has been reported by several studies. The amount of SOA formed is greatly underpredicted by SOA models which only consider SOA formation from volatile organic compounds (VOCs) (sometimes referred to as "traditional" SOA models, meaning those in use before 2006) (Volkamer et al., 2006; Kleinman et al., 2007; Dzepina et al., 2009; Fast et al., 2009; Hodzic et al., 2009; Tsimpidi et al., 2010; Wood et al., 2010). The amount of SOA observed after a few hours of photochemistry is several-fold the initial POA concentration. This is consistent with results at many other locations (e.g. de Gouw and Jimenez, 2009, and references therein; Hallquist et al., 2009). Models which include SOA formation from semivolatile and intermediate volatility species (S/IVOCs) predict much larger amounts of SOA that match or even exceed the observations, although the intensive properties of the SOA (volatility, O/C) are not well predicted and the level of mechanistic understanding remains low (Dzepina et al., 2009; Tsimpidi et al., 2010; Hodzic et al., 2010).

The addition of SOA to primary urban emissions in pollution-dominated airmasses can be estimated by ratios of OA to (approximately) conserved tracers to remove the effect of dilution of polluted airmasses with cleaner background air away from sources. Carbon monoxide (CO) has a lifetime against oxidation by $\mathrm{OH}$ of approximately one month in Mexico based on the measured $24 \mathrm{~h}$ average $\mathrm{OH}$ concentrations of $1.6 \times 10^{6} \mathrm{molec}^{-3}$ and thus can be used as a reasonably conserved tracer of emissions to account for dilution on timescales of hours to days. The variation of $\mathrm{CO}$ in this region is driven by the addition of $\mathrm{CO}$ from combustion sources (traffic and biomass burning) on top of a regional background. With the "CO-tracer method", POA is estimated from the measured $\mathrm{CO}$ (minus the $\mathrm{CO}$ background) and the POA/CO emission ratio while the difference between the total measured OA and the estimated POA is attributed to SOA (Takegawa et al., 2006; Docherty et al., 2008). Several aircraft-based studies have similarly used $\mathrm{CO}$ as a conservative tracer (e.g. Kleinman et al., 2007; Peltier et al., 2007; de Gouw et al., 2008; Dunlea et al., 2009) to study OA formation and evolution. Additional studies have observed a strong correlation between primary or total OA and CO (Zhang et al., 2005b; Kleinman et al., 2007; Peltier et al., 2007). A brief description of the OA vs CO relationship for this dataset was given in DeCarlo et al. (2008) but a more in-depth examination of this ratio is of interest to place our observations in the context of other studies in Mexico City and elsewhere, and to evaluate the effect of very different biomass burning influences.

"Open" biomass burning from forest fires and some agricultural burning near Mexico City was an important source of 
OA during MILAGRO. Yokelson et al. (2007) compared estimated fire PM amounts from aircraft-based emission measurements to the emissions inventory from the Mexico City metropolitan area and estimated that $\sim 79-92 \%$ of the primary particle mass generated in the Mexico City area is from forest fires near Mexico City, and $\sim 50 \% \pm 30 \%$ of the aged $\mathrm{PM}_{2.5}$ (not just of the $\mathrm{OA}$ ) is from fires. However these authors estimated the urban primary contribution from the MCMA emissions inventory, which has been shown to substantially underestimate primary fine particles (Aiken et al., 2009b; Fast et al., 2009; Zavala et al., 2009), and also assumed a doubling of the $\mathrm{POA} / \triangle \mathrm{CO}$ ratio for $\mathrm{BB}$ plumes due to SOA formation, which is likely too large as discussed below, and thus the actual percentage $\mathrm{BB}$ contribution to $\mathrm{PM}_{2.5}$ is likely lower. Querol et al. (2008) estimate that BB contributed about $10 \%$ of the $\mathrm{PM}_{2.5}$ during MILAGRO at the T0 urban supersite, which would correspond to about $18 \%$ of the OA. Source apportionment of organic carbon by Stone et al. (2008) found that $16 \%$ and $32 \%$ of the OC could be attributed to biomass burning at $\mathrm{T} 0$ and the rural supersite (T1) respectively. Similar fractional contributions are reported from analysis of AMS data at T0 by Aiken et al. (2009a). Aiken et al. (2009a) show that while absolute levels of biomass burning organic aerosol (BBOA) are lower in the afternoon, much higher column amounts of BBOA are present when scaling by boundary layer heights. Two ${ }^{14} \mathrm{C}$ datasets from Marley et al. (2009) and Aiken et al. (2009a) report about $15 \%$ higher modern carbon during the high-fire periods vs. the low-fire period, consistent with the quantification of biomass burning OA at T0 by Querol et al. (2008), Stone et al. (2008), and Aiken et al. (2009a). The substantial levels of modern carbon during periods of very low forest fires indicate that sources other than open biomass burning (e.g. cooking, regional biogenic SOA, biofuel use, trash burning etc.) contribute to the modern carbon fraction of OA in Mexico City. Another source apportionment study, using parts of the same aircraft dataset as this study, used constant ratios of OA to gas phase tracers of fire emissions and urban emissions and reported that approximately half of the organic aerosol during several afternoon flights could be attributed to fire sources above the city, decreasing to $\sim 25 \%$ at the surface, but with an even larger contribution on the regional scale (Crounse et al., 2009). Although forest fires near Mexico City were a large source of OA during MILAGRO, they were estimated to contribute $2-3 \%$ of the fine PM in Mexico City as an annual average, which is lower due to the seasonality of the fires (Aiken et al., 2009a). The contribution of more distant sources like the Yucatan (Yokelson et al., 2009) was small during MILAGRO (Aiken et al., 2009a) but is known to produce large impacts on Mexico City at other times (e.g. Salcedo et al., 2006).

This paper analyzes HR-ToF-AMS data taken on an aircraft platform in order to quantify the sources and processing of OA aloft during MILAGRO. The evolution of OA/ $\triangle \mathrm{CO}$ during contrasting periods of high and low BB is discussed.
PMF is applied to aircraft high-resolution AMS data for the first time. The use of high resolution (HR) data as opposed to unit mass resolution (UMR) data reduces ambiguity about factors, and improves the separation of factors by inclusion of individual ion signals instead of total signal at one $\mathrm{m} / \mathrm{z}$, which is especially important for the separation of BBOA from other components (Aiken et al., 2009b). PMF was applied to a combined dataset of two selected flights during the MILAGRO campaign with very different levels of open BB influence. The BBOA factor correlates well with Fire Impact Factors (FIF) calculated from FLEXPART dispersion modeling, consistent with results at T0 (Aiken et al., 2009a). Postprocessing of PMF results allows for better apportionment the OA mass to specific sources (BB vs. urban plus non-BB regional sources), and a comparison to the results of Crounse et al. (2009) is presented.

\section{Methods}

\subsection{Measurements and regressions}

Measurements of gas-phase $\mathrm{CO}, \mathrm{NO}, \mathrm{NO}_{2}, \mathrm{O}_{3}$, and $\mathrm{HCN}$ were performed with custom instruments on the NCAR/NSF C-130 research aircraft. Aerosol measurements were made with the High Resolution Aerosol Mass Spectrometer (HRToF-AMS, DeCarlo et al., 2006). A more detailed description of the instruments used in this study, the quantification and data analysis techniques, and instrumental intercomparisons can be found in DeCarlo et al. (2008) and Dunlea et al. (2009). The atomic O/C ratio of OA is calculated from the HR spectra with the method of Aiken et al. (2007, 2008). This paper will focus on the data from two Research Flights (RF) during the MILAGRO campaign, RF3 on 10 March 2006 and RF12 on 29 March 2006, which are selected based on excellent data coverage and quality and very different amounts of open biomass burning influence. A Google Earth image with the flight tracks of these 2 flights can be found in Supplementary Information Fig. SI-1, http://www.atmos-chem-phys.net/10/5257/2010/ acp-10-5257-2010-supplement.pdf. All linear regressions were performed using the Orthogonal Distance Regression routine, as implemented in the ODRPACK95 in Igor Pro 6 (Wavemetrics, Lake Oswego, OR) software package.

\subsection{Methods for $\mathrm{OA} / \Delta \mathrm{CO}$ analyses}

\subsubsection{Conceptual framework}

The conceptual framework for the application of the $\mathrm{OA} / \Delta \mathrm{CO}$ method and the determination of the CO background is shown in Fig. 1. In the source region, $\mathrm{OA} / \triangle \mathrm{CO}$ is related to the emission ratios of the main sources of OA and $\mathrm{CO}$, their relative strengths, and SOA formation, while on the regional scale, aloft, and in the absence of wet deposition, the dominant processes affecting $\mathrm{OA} / \Delta \mathrm{CO}$ are mixing of the 


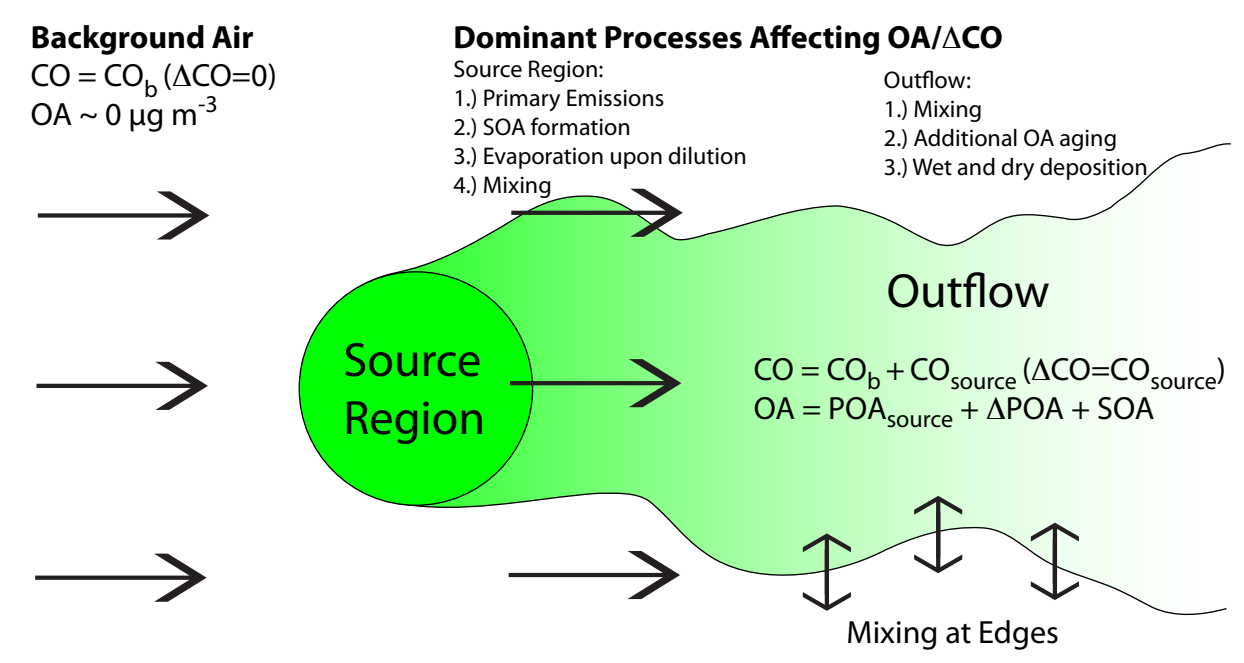

Fig. 1. A conceptual schematic for the application of the OA/ $\triangle \mathrm{CO}$ method, and the interpretation of the CO background for the present dataset.

source region plume with clean regional air and any additional evolution of OA (additional SOA formation, oxidation, volatilization, etc.). When the source region is a large urban area, the "CO-tracer method" described above uses this conceptual framework to estimate SOA formation by characterizing the overall primary $\mathrm{OA} / \triangle \mathrm{CO}$ emission ratio and assigning increases in the $\mathrm{OA} / \triangle \mathrm{CO}$ ratio to $\mathrm{SOA}$ formation (Takegawa et al., 2006; Docherty et al., 2008). However, in the presence of strong BB sources which can have very high $\mathrm{POA} / \triangle \mathrm{CO}$ ratios, the interpretation of the results from this method is more complex. DeCarlo et al. (2008) showed that for this region the $\mathrm{OA} / \triangle \mathrm{CO}$ ratio ceases to increase on the regional scale, yet the aerosol continues to become more oxidized. This behavior indicates that OA aging continues even after no additional SOA mass is formed, consistent with the conceptual framework proposed by Jimenez et al. (2009) and the results of Dunlea et al. (2009) who report continuing OA aging on timescales of nearly 1 week.

\subsubsection{Estimation of $\mathrm{CO}$ background}

In order to investigate the evolution of $\mathrm{OA} / \triangle \mathrm{CO}$, a determination of the CO background is necessary. The relevant $\mathrm{CO}$ background is that of the air into which the emissions of interest (in this case from Central Mexico) were injected; it has lost the OA that was associated with the background $\mathrm{CO}$ due to e.g. wet deposition, and thus the background $\mathrm{CO}$ can vary in time and between different regions. The largescale background $\mathrm{CO}$ in Central Mexico arises from longdistance transport and large-scale photochemical production (from $\mathrm{CH}_{4}$ and other organic species) in roughly equal proportions (Emmons et al., 2010). In and around the Mexico City Metropolitan Area (MCMA), $\triangle \mathrm{CO}$ (CO above back- ground) is mainly associated with anthropogenic combustion and biomass burning, with some contribution from the oxidation of hydrocarbons, but the latter process is expected to be diffuse and not affect correlations. Based on the conceptual framework in Fig. 1, the regression of OA vs. $\mathrm{CO}$ for regional air aloft would have an $\mathrm{x}$-intercept (when $\mathrm{OA}=0$ ) of the CO background value. Table 1 of DeCarlo et al. (2008) shows the results of this regression for all flights with AMS data for MILAGRO.

A test for the robustness in the determination of the $\mathrm{CO}$ background is to examine the transition regions where the urban plume and clean regional air are mixing, and perform the regression only on the subset of data in the plume-to-clean-air mixing transition. Figure SI-2, http://www.atmos-chem-phys.net/10/5257/2010/ acp-10-5257-2010-supplement.pdf shows the results of this method for RF3. The CO background value calculated from the regression of plume-edge-only data is $55 \pm 7 \mathrm{ppbv}$, and is very close to the value of $60 \mathrm{ppbv}$ found using all data less than 200 ppbv CO, as in DeCarlo et al. (2008). The criterion of all data less than $200 \mathrm{ppbv}$ provides more data points for the regression and removes the subjective interpretation of what constitutes a plume edge, so results from Table 1 in DeCarlo et al. (2008) will be used for the remainder of the paper: $\mathrm{CO}$ background values of $60 \mathrm{ppbv}$ and $93 \mathrm{ppbv}$ are used for RF3 and RF12, respectively. In general, the regional background of $\mathrm{CO}$ is lower in Mexico than the East Coast of the United States due to cleaner air advecting into Central Mexico from the Pacific Ocean (Emmons et al., 2010).

As a side point, the plume mixing edge data in Fig. SI-2 http://www.atmos-chem-phys.net/10/5257/2010/ acp-10-5257-2010-supplement.pdf can also be used to provide a first-order evaluation of the degree of evaporation of 
the regional aged $\mathrm{OA}$ upon dilution. Using a $\mathrm{CO}$ concentration of $200 \mathrm{ppbv}$ and the calculated background value for RF 3 (60 ppbv), one can calculate the CO concentration as a function of dilution ratio for the dilution of the 200ppbv plume with 60ppbv background air. A modeled OA concentration can also be determined as a function of dilution ratio assuming a starting concentration of $10 \mathrm{ug} / \mathrm{m} 3$. The blue line in Fig. SI-2, http://www.atmos-chem-phys.net/10/ 5257/2010/acp-10-5257-2010-supplement.pdf the graph is the modeled volatile loss of OA from dilution for a combination of state-of-the art SOA models for Mexico City, as described in Dzepina et al. (2009). Most of the datapoints lie around the straight line and above the dilution line, which suggests that the volatility of the OA predicted by current models is overestimated, consistent with results of direct volatility measurements in Mexico City (Cappa and Jimenez, 2010; Huffman et al., 2009a).

\subsubsection{Primary $\mathrm{OA} / \Delta \mathrm{CO}$ ratio for urban and $\mathrm{BB}$ plumes}

Reports of the ratio $\mathrm{POA} / \triangle \mathrm{CO}$ for urban sources vary in the range $\sim 2-16 \mu \mathrm{g} \mathrm{sm}^{-3} \mathrm{ppmv}^{-1}$, although the higher values likely contain some SOA (de Gouw and Jimenez, 2009, and references therein). Urban $\mathrm{POA} / \Delta \mathrm{CO}$ ratios of $\sim 7$ $8 \mu \mathrm{g} \mathrm{sm}^{-3} \mathrm{ppmv}^{-1}$ in Mexico City have been estimated from the ground-based Mexico City data of Salcedo et al. (2006), Aiken et al. (2009b), and Wood et al. (2010).

Reported values of emitted $\mathrm{POA} / \triangle \mathrm{CO}$ and ambient $\mathrm{OA} / \triangle \mathrm{CO}$ vary widely for biomass burning $(\mathrm{BB})$, in a range at least spanning $50-200 \mu \mathrm{g} \mathrm{sm}^{-3} \mathrm{ppmv}^{-1}$ (de Gouw and Jimenez, 2009). Most relevant to this study are the values from Yokelson et al. (2007) who report an average value of $148 \mu \mathrm{g} \mathrm{sm}^{-3} \mathrm{ppmv}^{-1}$, with a range of 91$242 \mu \mathrm{g} \mathrm{sm}^{-3} \mathrm{ppmv}^{-1}$ for 5 pine-savanna fires around the Mexico City basin during the MILAGRO campaign. For primary BBOA (P-BBOA), the ratios to $\Delta \mathrm{CO}(\mathrm{P}-\mathrm{BBOA} / \Delta \mathrm{CO})$ are more than an order of magnitude higher than for urban POA, which make the estimation of SOA in Mexico City using the CO-tracer method very difficult during periods in which BB is prevalent. Fortunately, the influence of BB, as measured by e.g. fire satellite counts and fire tracers, varied widely during MILAGRO due to varying meteorological conditions and precipitation (Fast et al., 2007; de Foy et al., 2008; Aiken et al., 2009a). This variation provides contrasts between different periods (such as RF3 and RF12) that can be used to evaluate the influences of BBOA vs. pollution SOA on $\mathrm{OA} / \triangle \mathrm{CO}$ and other variables.

Another factor to consider when examining the $\mathrm{POA} / \Delta \mathrm{CO}$ ratios is the potential effect of evaporation upon dilution. Both urban POA and P-BBOA have been shown to be semivolatile, evaporating a substantial fraction of their mass upon dilution from source levels $\left(\mathrm{mg} \mathrm{m}^{-3}\right)$ to ambient concentrations (few $\mu \mathrm{g} \mathrm{m}^{-3}$ ), or upon light heating (Shrivastava et al., 2006; Robinson et al., 2007; Cappa and Jimenez, 2010; Grieshop et al., 2009b; Huffman et al., 2009a). This may reduce the $\mathrm{POA} / \triangle \mathrm{CO}$ ratio compared to ratios determined under very high source concentrations. For urban POA the evaporation is thought to occur on a timescale of minutes (Zhang and Wexler, 2004; Zhang et al., 2004); thus urban $\mathrm{POA} / \triangle \mathrm{CO}$ ratios measured in the urban background or from aircraft should not be significantly perturbed by additional evaporation. On the other hand, the dilution of large BB plumes with hundreds or even a few thousand $\mu \mathrm{g} \mathrm{m}^{-3}$ of OA to concentration levels more typical of ambient atmosphere can take much longer, and since BB plumes can be injected higher into the atmosphere, this effect needs to be considered for aircraft datasets. The P-BBOA $/ \triangle \mathrm{CO}$ ratio of a biomass burning plume is therefore likely to be a function of distance from source and dilution. Thus P-BBOA/ $\triangle \mathrm{CO}$ numbers such as reported by Yokelson et al. (2007) from very fresh and concentrated smoke are likely upper limits, and the ratios in the more dilute outflow can be expected to be lower. If the fresh high-concentration P-BBOA from the forest fire plumes during MILAGRO has volatility characteristics similar to those reported by Shrivastava et al. (2006) and Cappa and Jimenez (2010), we can estimate that the P-BBOA/ $\Delta \mathrm{CO}$ ratio can be reduced by a factor of $2-4$ due to this effect. As discussed below, much of the evaporated mass may return to the particle phase after gas-phase oxidation, forming SOA.

\subsubsection{Evolution of $\mathrm{SOA} / \Delta \mathrm{CO}$ for urban and BB plumes}

Dzepina et al. (2009) summarized $\mathrm{OA} / \Delta \mathrm{CO}$ ratio from secondary formation during the MCMA-2003 campaign, as well as from two studies during MILAGRO (Kleinman et al., 2008; de Gouw et al., 2008). The $\mathrm{OA} / \Delta \mathrm{CO}$ ratio from urban emissions reaches $\sim 35 \mu \mathrm{g} \mathrm{sm}^{-3} \mathrm{ppmv}^{-1}$ after $\sim 0.4$ days of photochemical age, and larger values of up to $\sim 80 \mu \mathrm{g} \mathrm{sm}^{-3}$ $\mathrm{ppmv}^{-1}$ may be reached after about a day of photochemistry for periods of low BB emissions (DeCarlo et al., 2008; Kleinman et al., 2008). This suggests that SOA formation is rapid, with about half of the SOA formed in short timescales of $\sim 1 / 2$ day. In general, the $\mathrm{OA} / \Delta \mathrm{CO}$ values measured for aged polluted airmasses in Mexico are consistent with the range of values reviewed by de Gouw and Jimenez (2009).

The quantification of SOA formation from concentrated BB plumes is more complex due to the competing effects of evaporation and SOA formation which occur at the same time. As it is very difficult at present to constrain the PBBOA vs. secondary BBOA (S-BBOA) fractions of total BBOA using direct measurements, a more direct approach is to characterize the net effect of aging (including both evaporation and SOA formation) in total BBOA mass (de Gouw and Jimenez, 2009). This net effect of aging in OA mass in ambient BB plumes is poorly constrained in the literature (Reid et al., 2005), with some studies finding increases of aerosol mass relative to inert tracers on very short time scales (Babbitt et al., 1997; Yokelson et al., 2009), and others a decrease or constant levels (Liousse et al., 1995; Andreae et al., 1998; Capes et al., 2008). Yokelson et al. (2009) reported 
a doubling of the OA mass (i.e. net effect of aging in OA mass $\sim$ P-BBOA) for a plume from agricultural burning in the Yucatan. In a pseudo-Lagrangian study of savanna fires in Africa, Capes et al. (2008) saw little change in the OA/ $\Delta \mathrm{CO}$ ratio of fire emissions several days downwind (i.e. net effect $\sim 0$ ); however. the aerosol was increasingly oxygenated in transport, implying SOA formation had occurred but without a net increase in OA mass. Hecobian et al. (2010) also report a lack of net SOA formation in plumes from boreal forest fires during the ARCTAS campaign. Yokelson et al. (2009) report that biomass burning can be a strong source of HONO, which photolyzes very quickly to $\mathrm{OH}+\mathrm{NO}$, leading to very rapid initial photochemistry, and complicating the definition of the initial P-BBOA state. The reasons for the reported variability across different studies are unclear, but may be due to differences in the type of biomass and its burning conditions (flaming vs. smoldering). E.g. very large variability in the volatility of P-BBOA from open burning in the laboratory has been recently reported (Huffman et al., 2009b), which may strongly influence both P-BBOA evaporation and the amount of SOA formed from semivolatile aging (Robinson et al., 2007).

\subsection{Methods for PMF analysis}

\subsubsection{PMF model description}

PMF is a bilinear unmixing model which identifies factors which serve to approximately reconstruct the measured organic mass spectra for each point in time; each factor is comprised of a (constant) mass spectrum and a time series of mass concentration and all values in the factors are constrained to be positive. The model is solved by minimizing the sum of the weighed squared residuals of the fit (known as Q). The PMF model using as inputs the high-resolution OA mass spectral matrix and associated error matrix described in the following section was solved with the PMF2.exe algorithm v.4.2 (Paatero and Tapper, 1994; Paatero, 2007). Results were investigated using the Igor Pro-based PMF Evaluation Tool (PET) developed to allow rapid and comprehensive exploration of the PMF2 solution space (Ulbrich et al., 2009). The application of PMF to AMS OA spectra has been described in detail previously (Lanz et al., 2007; Ulbrich et al., 2009).

\subsubsection{HR data and error matrix preparation for PMF}

High resolution data were processed according to the methods detailed in DeCarlo et al. (2006; 2008). The high resolution data matrix was generated by the difference of the "open" (particle beam + background) and "closed" (background only) high resolution ion areas (Jimenez et al., 2003; DeCarlo et al., 2006). Negative values resulting from the difference of the open and closed mass spectra were set to zero in the data matrix. In addition, only ions originating from organic species with $m / z \leq 100$ were included in the data matrix. The corresponding error matrix used in the PMF algorithm was estimated as the sum in quadrature of Poisson counting statistics and electronic noise for each ion in the data matrix, according to the procedure detailed in Allan et al. (2003) and Ulbrich et al. (2009). This method may underestimate the true error, especially for smaller ion signals adjacent to larger ion signals, as it does not account for error in the high resolution fitting procedure, but it is a robust estimate of the error for the most important ions at each nominal $\mathrm{m} / \mathrm{z}$, as discussed below. Indeed the values of the normalized $Q$ values $\left(Q / Q_{\text {expected }}\right)$ for the PMF solutions considered here are of the order of 1 (Fig. A1), as expected when the errors are properly specified. Air interference for some specific ions (e.g. $\mathrm{CO}_{2}^{+}$) was subtracted using the same procedures specified in the unit mass resolution (UMR) fragmentation table (Allan et al., 2004), and the errors from the subtraction were propagated in the error matrix. In addition, $\mathrm{CO}^{+}, \mathrm{H}_{2} \mathrm{O}^{+}, \mathrm{OH}^{+}$, and $\mathrm{O}^{+}$were added to the data and error matrix as $1,0.225,0.0563$, and 0.0141 times the concentration of the particulate $\mathrm{CO}_{2}^{+}$ion signal, as suggested by Aiken et al. (2008), and downweighed before PMF analysis as discussed by Ulbrich et al. (2009). "Bad" ions with low signalto-noise (SNR), defined as an average SNR over the whole data set of 0.2 or less, were removed from the data and error matrices (Paatero and Hopke, 2003). "Weak" ions (ions with SNR between 0.2 and 2) were not downweighted for this analysis. Lastly, error values in the matrix less than $0.05 \mathrm{~Hz}$ were set to $0.05 \mathrm{~Hz}$ to account for the minimum amount of noise observed in the data. Both the data and error matrices were converted from ion signal $\mathrm{Hz}$ to mass concentrations under standard pressure and temperature $\left(\mu \mathrm{g} \mathrm{m}^{-3}\right.$ under STP or $\mu \mathrm{g} \mathrm{sm}^{-3}, 1013.25 \mathrm{hPa}$ or $1 \mathrm{~atm}$ and $273 \mathrm{~K}$ ). The mass spectral datasets from RF3 and 12 were combined into a single dataset, with the mass spectral matrix (mass spectra vs time) from RF12 appended as rows to the mass spectral matrix from RF3. PMF2 was run on the combined dataset to force retrieved mass spectral profiles to be identical for both flights. Additionally, each flight was run independently (not shown), and similar results were found, with the main difference being that for RF12 only 3 factors were retrieved (no BBOA factor was found).

\subsection{Fire Impact Factor FIF from WRF-FLEXPART modeling}

The calculation of Fire Impact Factors (FIF) has been described in detail in Aiken et al. (2009a). Briefly, satellite data on number and location of fires from the MODIS-Terra, MODIS-Aqua, and GOES satellite sensors were used in conjunction with $\mathrm{CO}$ emissions estimated via the method of Wiedinmyer et al. (2006). Forward particle trajectories for CO were calculated with the WRF-FLEXPART Lagrangian dispersion model (Stohl et al., 2005; Doran et al., 2008) using wind fields from the Weather Research and Forecast (WRF) 
mesoscale meteorological model as described in de Foy et al. (2009b). Identical to Aiken et al. (2009a), two alternative diurnal emission scenarios were simulated, with emissions either from 12:00-20:00 Local Standard Time (LST, equivalent to UTC $-6 \mathrm{~h}$ ) or from 14:00-24:00 LST. Particle tracer counts were calculated for the aircraft flight track by counting the number of particles in a 10 by $10 \mathrm{~km}$ box centered on the current aircraft position. In the vertical, alternative FIFs were calculated for boxes extending 100, 500 and $1000 \mathrm{~m}$ above and below the flight altitude, as well as for the total vertical column.

\subsection{A note on correlations of species in aircraft data sets}

In this paper and in other studies, correlations between species are often used to evaluate when different pollutants have similar sources or arise from similar processes in the atmosphere. For regional pollution, correlations can be driven not just by co-located sources or processing behavior, but simply by measurements being made in and out of a pollution plume or well-mixed polluted airmass. Figure SI-3, http://www.atmos-chem-phys.net/10/5257/2010/ acp-10-5257-2010-supplement.pdf shows the correlation of aerosol $\mathrm{SO}_{4}$ and gas phase $\mathrm{HCN}$ in regional air during RF3. $\mathrm{SO}_{4}$ and $\mathrm{HCN}$ have different dominant sources in this region, namely volcanoes, power plants, and petrochemical facilities for $\mathrm{SO}_{4}$ (through secondary processes) vs. biomass burning for HCN (a primary emission). The correlation of these 2 pollutants in the regional outflow is driven by the aircraft entering and exiting the advected plume at varying distances from Mexico City. For the data in the city itself, it is clear that the individual sources and processes of these pollutants are not the same, but as they mix in the regional outflow, they correlate well on the regional scale. In the remainder of this paper, correlations will continue to be used as a metric for choice of PMF solutions, but the underlying reasons for the correlations must also be considered when interpreting the results.

\section{Results}

\subsection{Evolution of $\mathrm{OA} / \Delta \mathrm{CO}$ for RF3 and RF12}

The OA/ $\triangle \mathrm{CO}$ ratio for RF3 and RF12 is shown in Fig. 2 as a function of the organic $\mathrm{O} / \mathrm{C}$ atomic ratio (a surrogate for photochemical age), colored by $-\log _{10}\left(\mathrm{NO}_{\mathrm{x}} / \mathrm{NO}_{\mathrm{y}}\right)$ as another age surrogate (DeCarlo et al., 2008). A very different trend appears for each flight, with RF12 showing lowest values of $\sim 35 \mathrm{\mu g} \mathrm{sm}^{-3} \mathrm{ppbv}^{-1}$ for $\mathrm{O} / \mathrm{C} \sim 0.45$ over the urban area, entirely consistent with the values observed in the urban area at the ground and from the G-1 aircraft in the early afternoon (Kleinman et al., 2008; de Gouw et al., 2009; Dzepina et al., 2009). The more aged air observed in RF12 shows increased $\mathrm{O} / \mathrm{C}$ up to about 0.9 and $\mathrm{OA} / \Delta \mathrm{CO}$ centered around $80 \mu \mathrm{g} \mathrm{sm}^{-3} \mathrm{ppbv}^{-1}$ (range $\sim 50-120$ ), also consistent

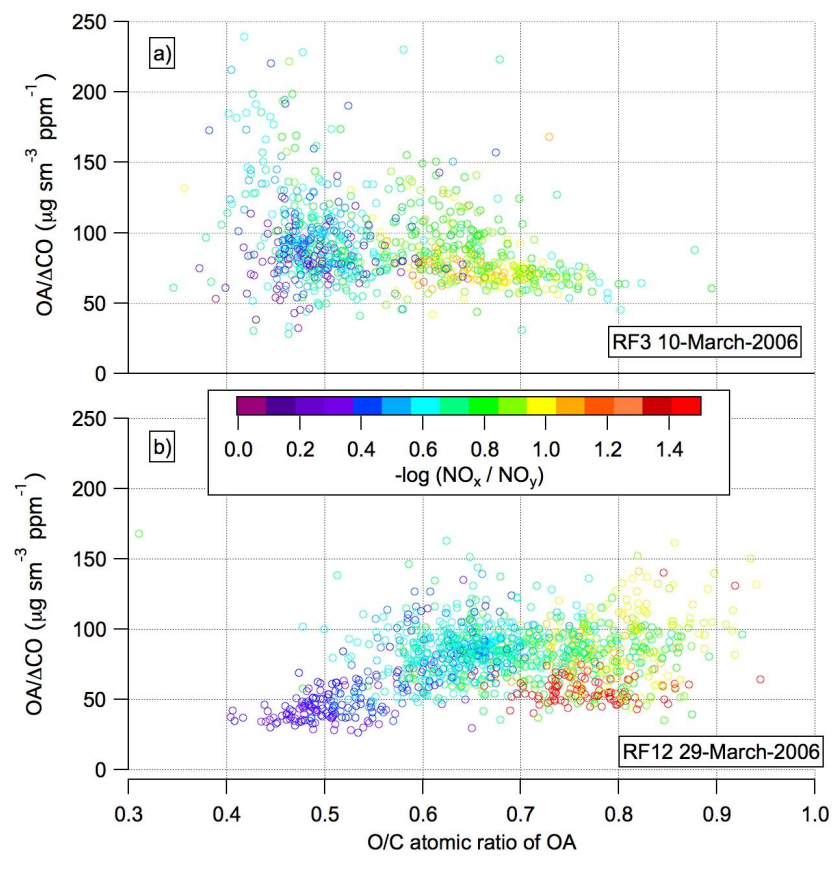

Fig. 2. The $\mathrm{OA} / \Delta \mathrm{CO}$ ratio vs. the $\mathrm{O} / \mathrm{C}$ atomic ratio of Organic Aerosol for RF3 (part a) and RF12 (part b). The color of the points is given by $-\log _{10}\left(\mathrm{NO}_{\mathrm{x}} / \mathrm{NO}_{\mathrm{y}}\right)$. The influence of biomass burning is clear in the higher $\mathrm{OA} / \triangle \mathrm{CO}$ values shown for low $\mathrm{O} / \mathrm{C}$ ratio in RF3. RF12 shows increasing $\mathrm{OA} / \Delta \mathrm{CO}$ ratios with photochemical age indicating SOA formation with aging.

with previous reports (DeCarlo et al., 2008; Kleinman et al., 2008). As discussed in DeCarlo et al. (2008), the increasing $\mathrm{O} / \mathrm{C}$ with a reasonably stable $\mathrm{OA} / \Delta \mathrm{CO}$ implies that some organic carbon is lost from the aerosol phase as organic oxygen is gained, consistent with recent laboratory studies of OA aging under high oxidant levels (George et al., 2008; Kroll et al., 2009).

The evolution for RF3, shown in Fig. 2a and Fig. SI4, http://www.atmos-chem-phys.net/10/5257/2010/ acp-10-5257-2010-supplement.pdf, follows a very different pattern. Fresher BB plumes have $\mathrm{O} / \mathrm{C}$ ratios in the range 0.3-0.45 (Aiken et al., 2008; DeCarlo et al., 2008), and high values of $\mathrm{OA} / \Delta \mathrm{CO}$ around $150 \mu \mathrm{g} \mathrm{sm}^{-3} \mathrm{ppbv}^{-1}$. As these plumes age and also mix with urban and regional pollution, $\mathrm{O} / \mathrm{C}$ reaches values of up to 0.8 while $\mathrm{OA} / \Delta \mathrm{CO}$ remains between $60-90 \mu \mathrm{g} \mathrm{sm}^{-3} \mathrm{ppbv}^{-1}$. An important reason for the decrease of $\mathrm{OA} / \triangle \mathrm{CO}$ for aged air in RF3 is the mixing with urban air with higher $\mathrm{CO}$ content. With our limited data set and the intricate mixing of urban and BB plumes in this study (see below, and also as described by Crounse et al., 2009), it is not possible to evaluate these processes for evolution upon aging of urban and $\mathrm{BB}$ airmasses using the $\mathrm{OA} / \Delta \mathrm{CO}$ analysis alone. I.e. a range of asymptotic "aged" values and aging timescales for urban and BB airmasses can reproduce the observed patterns, within the measurement scatter, and as the urban ratio is 


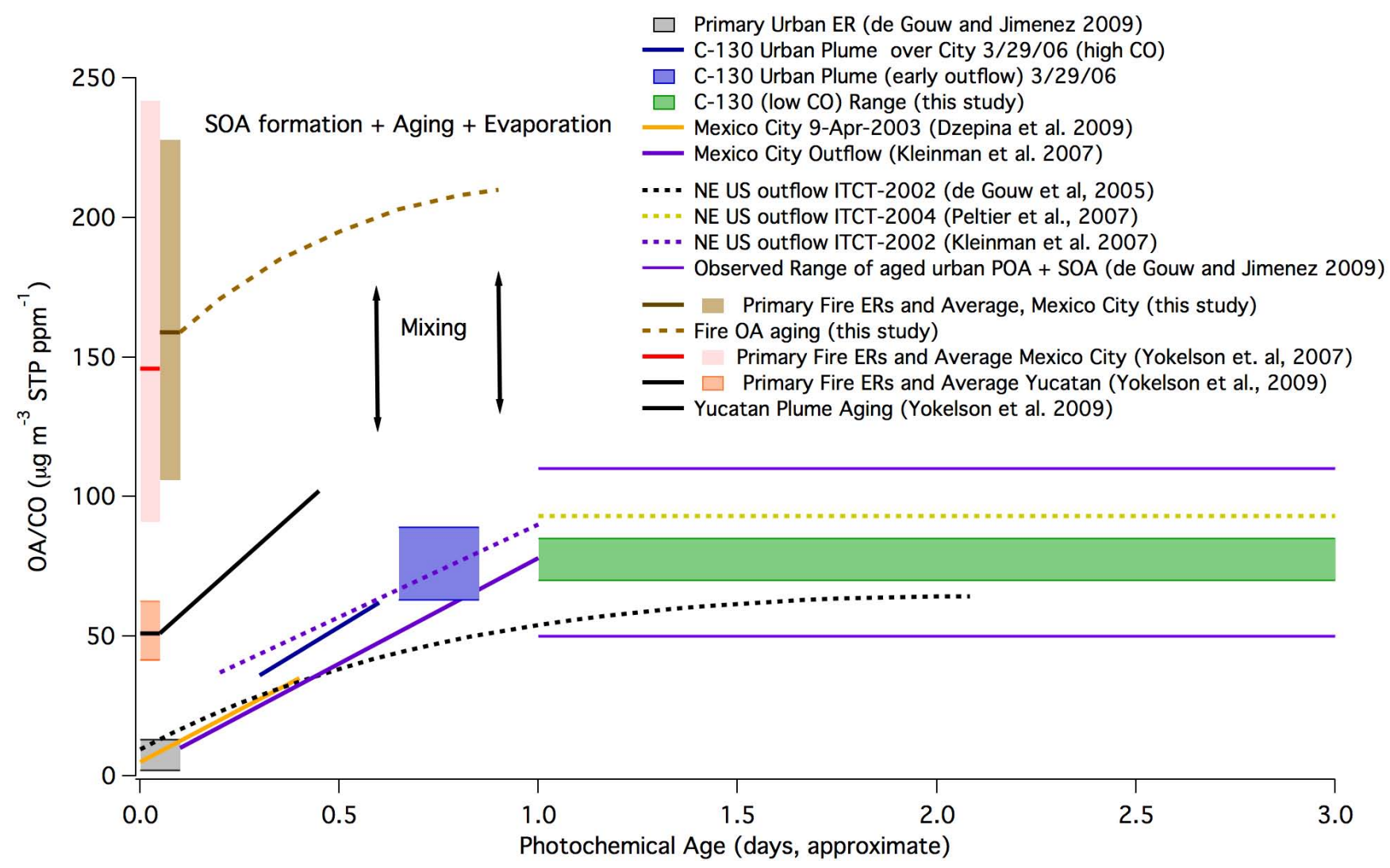

Fig. 3. A conceptual model of the evolution of the $\mathrm{OA} / \triangle \mathrm{CO}$ ratio as a function of photochemical age. For the MIRAGE campaign, data from flights with a city and regional component are given. Primary emissions ranges from Biomass burning are taken from Yokelson et al. (2007). for the Mexico City area. Primary emission ratios for urban emissions are taken from de Gouw and Jimenez (2009) and references therein. Evolution of outflow from the Eastern US during NEAQS evolution was provided as a personal communication by J. de Gouw and is based on the analysis from de Gouw et al. (2005).

increased the $\mathrm{BB}$ ratio is decreased and vice versa. Thus this topic is revisited below with the results of the PMF analysis and postprocessing. There is also likely some interaction between $\mathrm{BB}$ and urban airmasses in terms of chemistry and OA partitioning, which in principle would require a modeling study, although this is not possible at present as current models do not accurately capture OA aging and SOA formation. At other locations with more spatially distinct sources, it should be possible to better characterize the separate evolution of urban and BB airmasses using highly time-resolved $\mathrm{OA} / \triangle \mathrm{CO}$ data, as done for some previous studies (e.g. Capes et al., 2008; de Gouw et al., 2008; Yokelson et al., 2009).

Figure 3 presents an integrated schematic summarizing the $\mathrm{OA} / \triangle \mathrm{CO}$ ratios for POA and SOA and a conceptual interpretation of the $\mathrm{OA} / \triangle \mathrm{CO}$ evolution in the absence of large aerosol loss processes (e.g. rainout) based on results from this study and several previous studies in the Mexico City, the Northeast US, and other locations. In the absence of biomass burning, multiple studies report the rapid addition of SOA mass in urban air greatly exceeding the initial ur- ban POA emission ratios on the timescale of a day. It is interesting to note that the northeastern US and Mexico share the same trend and approximate magnitudes of SOA/ $\triangle \mathrm{CO}$ increase for polluted airmasses, and are also generally consistent with other polluted locations (Heald et al., 2008; de Gouw and Jimenez, 2009). P-BBOA/ $\Delta \mathrm{CO}$ ratios from fires near the MCMA start considerably higher than the $\mathrm{OA} / \Delta \mathrm{CO}$ measured regionally in Central Mexico, reflecting the mixing with CO-rich urban pollution, and do not appear to largely perturb the regional $\mathrm{OA} / \triangle \mathrm{CO}$ ratios. The net effect of evaporation and SOA formation on total BBOA is revisited below.

\subsection{PMF results}

The timeseries and the mass spectra of the four-factor PMF solution chosen for the combined flights (RF3 and RF12) are given in Figs. 4 and 5 respectively. This solution was chosen after extensive analysis of how the number of factors, FPEAK rotational parameter, and initial random starts ("seeds"), changed the results, as discussed in Appendix A. Analysis of the variability in the seed solutions was 


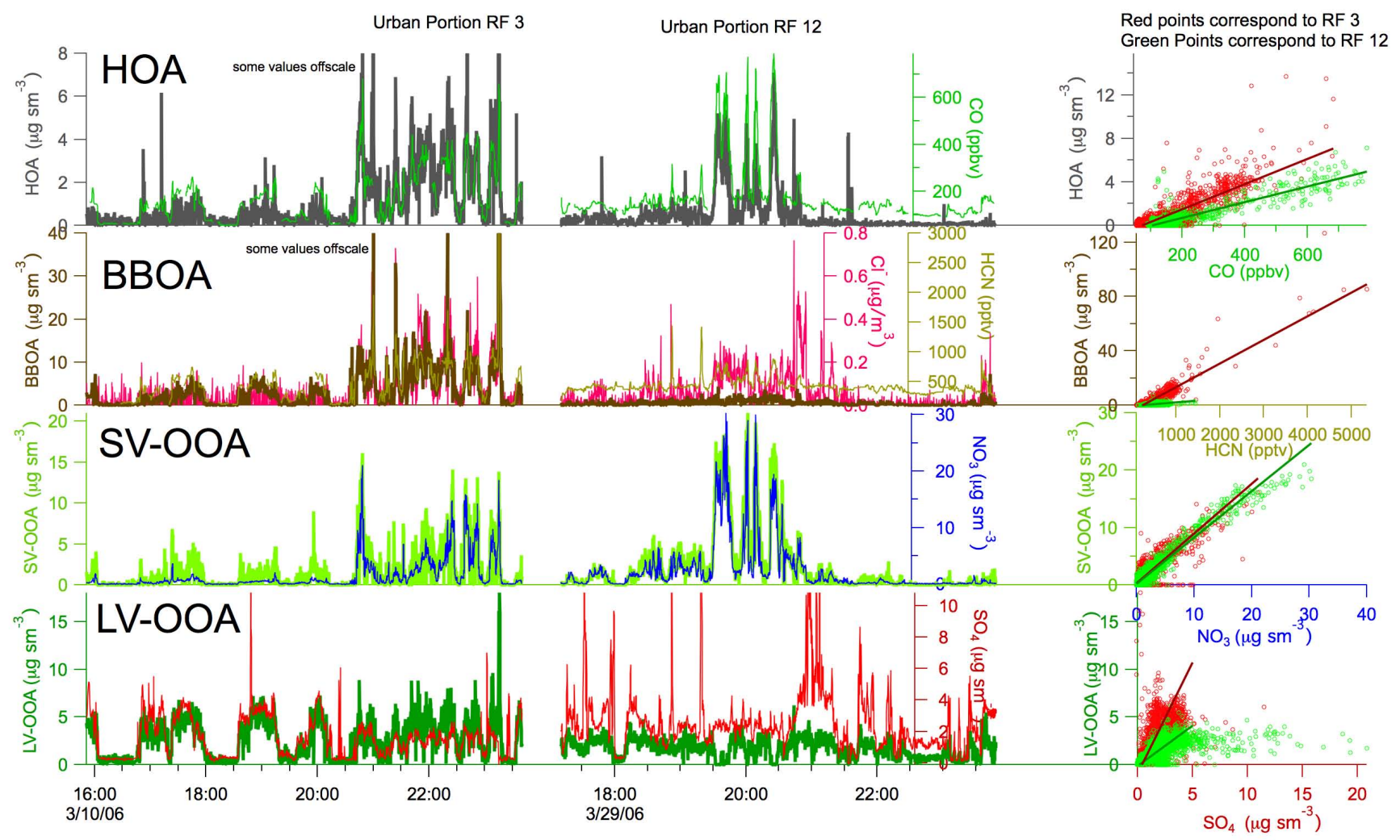

Fig. 4. Time series of the 4 factor PMF solution with tracer species for each factor. Scatter plots to the main tracers are shown to the right of the timeseries, with red points corresponding to RF3 and green points corresponding to RF12. Regression statistics of Pearson R and slope can be found in Fig. A2.

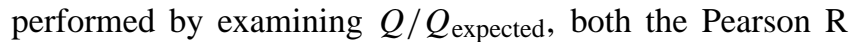
and the slope of regressions of the factors to known tracers, and the total $R^{2}$ of the time series of each solution with tracers (Fig. A1), for both RF3 and RF12 (Fig. A2). The combination of RF3 and RF12 datasets resulted in the retrieval of a minor BBOA factor $(\sim 10 \%$ of the OA mass) in RF12, not present when running each flight individually. Based on known PMF behavior (Ulbrich et al., 2009) this BBOA factor in RF12 could either be real (i.e. an OA component that is present but too weak to be retrieved by PMF when running RF12 alone) or an artifact of the PMF analysis (by providing another spectrum to fit the data, some of the mass in RF12 goes with this factor even if very little BBOA was present). Figure 4 shows the time series of the PMF components along with key tracer species. The four factors retrieved are HOA, BBOA, low-volatility OOA (LV-OOA), and semivolatile OOA (SV-OOA). LV-OOA corresponds to OOA- 1 and SV-OOA corresponds to OOA-2 from previously published PMF-AMS datasets (Lanz et al., 2007; Aiken et al., 2008; Lanz et al., 2008; Ulbrich et al., 2009). The naming based on volatility has been recently adopted on the basis of several studies showing a relationship between higher oxygenation and lower volatility (e.g. Lanz et al., 2007; Huffman et al., 2009a; Jimenez et al., 2009; Ulbrich et al., 2009; Cappa and Jimenez, 2010). Figure 5 shows the mass spectral profiles (MS) for the different PMF factors, and the corresponding elemental composition for each factor. A discussion of each factor follows.

\subsubsection{Hydrocarbon-like organic aerosol, HOA}

The MS of this component is similar to lubricating oil/long chain hydrocarbons and partially burned fuel, consistent with its low $\mathrm{O} / \mathrm{C}$ ratio of 0.06 , and is consistent with many previous studies in Mexico City (e.g. Aiken et al., 2009b; Dzepina et al., 2009) and other urban areas (e.g. Zhang et al., 2005a; Lanz et al., 2007; Zhang et al., 2007; Ulbrich et al., 2009). A strong correlation with $\mathrm{CO}(R=0.79)$ was found, with the slope varying between flights, $11.6 \mu \mathrm{g} \mathrm{sm}^{-3} \mathrm{ppm}^{-1}$ in RF3 and $7.2 \mu \mathrm{g} \mathrm{sm}^{-3} \mathrm{ppm}^{-1}$ in RF12. Part of the difference in slope is likely due to part of the HOA factor being due to biomass burning emissions during RF3 $\left(R^{2}\right.$ value of HOA with $\mathrm{HCN}=0.7$ for RF3). All investigated seed solutions (excluding one solution with low HOA to CO correlation) in RF3 have regression slopes systematically higher compared to RF12, indicating this is a general observation for this dataset. This is likely due to the fact that RF3 sampled 


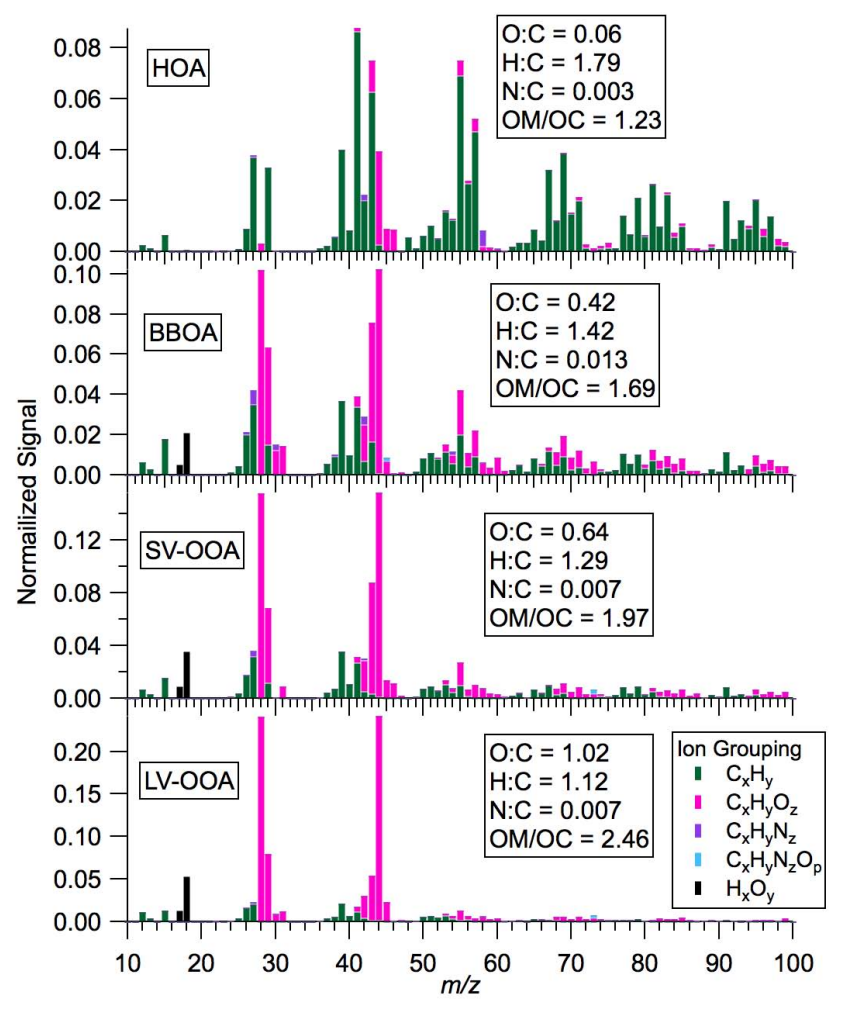

Fig. 5. Mass spectra of the 4 factor PMF solution with the corresponding elemental analysis of the mass spectra giving $\mathrm{O} / \mathrm{C}, \mathrm{H} / \mathrm{C}$, $\mathrm{N} / \mathrm{C}$ atomic ratios and the $\mathrm{OM} / \mathrm{OC}$ ratio.

a large dynamic range of photochemical ages for BBOA, so the true spectra of BBOA are variable, not constant. PMF fits a fixed MS for each factor, which often represents an average of the sampled states, and thus the BBOA factor is dominated by a partially aged spectrum. A less oxidized BBOA spectrum can be approximated by the combination of the PMF retrieved HOA + BBOA mass spectral profiles, to best fit the measured data. In Sect. 3.5 we have produced a "postprocessed" PMF solution in which we will use the difference in slope of HOA vs. CO to add some HOA mass to the BBOA component (for RF3 only). This may allow a potentially more correct apportionment of OA to sources, rather than the grouping by chemical similarity produced by the direct PMF output.

\subsubsection{Biomass burning organic aerosol, BBOA}

During RF3 the BBOA factor accounts for a substantial fraction of the OA and appears to be dominated by biomass burning emissions, with high correlation to both $\mathrm{HCN}$ and aerosol chloride. Its importance is much reduced in RF12 when fire activity was much lower. The high $\mathrm{m} / \mathrm{z}, 44$ in the MS of this factor and the reduced signal at larger $\mathrm{m} / \mathrm{z}$ compared to PBBOA MS from PMF analysis at T0 and from laboratory open burning of pine (the forests near the MCMA are mainly pine forests) (e.g. Fig. 7 of Aiken et al., 2009b), indicate that this factor probably contains some S-BBOA, although the fraction of P-BBOA vs. S-BBOA is difficult to estimate. Similarly, the MS of this factor compares better to the "aged BBOA" than the P-BBOA for smog chamber aging to woodstove emissions (Grieshop et al., 2009a). Finally, many of the fire plumes intercepted by the C-130 were sampled several hours after emission during the mid-afternoon and had time for photochemical aging and SOA formation. With increased residence time in the atmosphere the material in the BBOA factor will be further oxidized and begin to transition into LV-OOA type material (Jimenez et al., 2009). In general the BBOA factor captures the majority of the fire-associated aerosol, and its time series is consistent with the general observations of very reduced fire activity later in the campaign.

\subsubsection{Semi-volatile oxygenated organic aerosol, SV-OOA}

Based on strong correlations with submicron nitrate and $\mathrm{CO}$ (Pearson $\mathrm{R}=0.93$ and 0.88 respectively), this component is thought to be dominated by relatively fresh urban SOA. Its MS is more oxidized than the MS of fresh urban SOA from other studies in Mexico City (e.g. Aiken et al., 2009b; Dzepina et al., 2009; Huffman et al., 2009a). This could be due to the timing of the flights in the afternoon, well after the onset of SOA formation in the Mexico City basin. This factor is unlikely to have an important contribution from $\mathrm{BB}$ emissions, as the Pearson R correlation with $\mathrm{HCN}$ is low at 0.4. Additionally, we can rule out a major contribution of biogenic SOA to SV-OOA for this dataset. Biogenic SOA makes a relatively small background contribution $\left(\sim 1 \mu \mathrm{g} \mathrm{m}^{-3}\right)$ to the Mexico City region during this period (Hodzic et al., 2009) which is far lower than the SVOOA levels (reaching $20 \mu \mathrm{g} \mathrm{sm}^{-3}$ ) observed in this dataset, and biogenic $\mathrm{CO}$ would also make low and slowly varying contributions which could not explain the intense plumes of $400-600 \mathrm{ppbv}$ of $\mathrm{CO}$ observed here. The $\mathrm{O} / \mathrm{C}$ atomic ratio of this factor, 0.64, is between the HOA (0.06) and BBOA $(0.42)$, and LV-OOA (1.02) ratios. Similar to the BBOA factor, increasing residence time in the atmosphere, and continued oxidation, is expected to evolve OA mass from this factor towards the LV-OOA factor on regional scales via processes such as gas-phase oxidation of semivolatiles and heterogeneous chemistry (Jimenez et al., 2009). A case study of this process is examined in Sect. 3.3. below.

\subsubsection{Low-volatility oxygenated organic aerosol, LV-OOA}

This is the most oxygenated of all OA components, and is similar to LV-OOA MS from many previous studies (e.g., Lanz et al., 2007; Aiken et al., 2008; Ulbrich et al., 2009). Its MS appears to represent an end-product of OA oxidation (Jimenez et al., 2009; Ng et al., 2010). The actual 


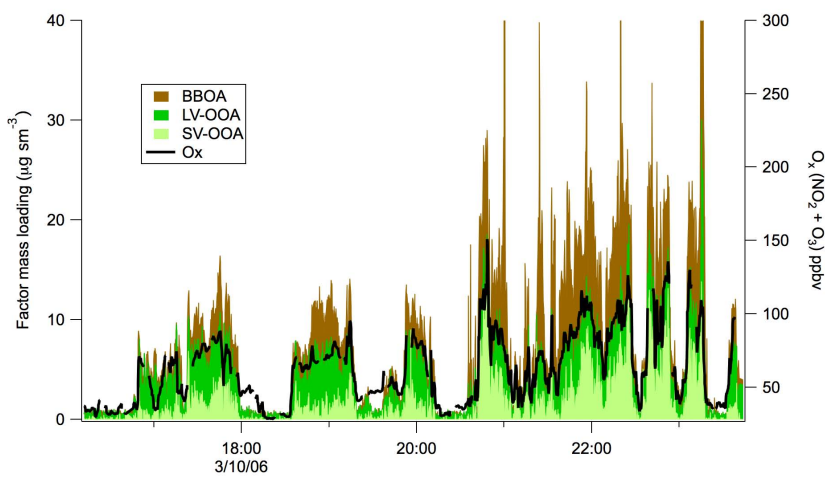

Fig. 6. The timeseries of stacked PMF factors for RF 3, showing the correlation between the sum of SV-OOA and LV-OOA and $\mathrm{O}_{\mathrm{x}}$.

sources of this factor cannot be determined from its MS as continued oxidation of many sources give MS similar to LVOOA (Jimenez et al., 2009). Correlation of this factor with $\mathrm{SO}_{4}$ has also been reported in other studies (e.g. Lanz et al., 2007; Ulbrich et al., 2009). This correlation (in and out of the city) is most likely due to the accumulation of both secondary products in regional aged air, as discussed in relation to Fig. SI-3, http://www.atmos-chem-phys.net/ 10/5257/2010/acp-10-5257-2010-supplement.pdf above, although cloud-processing or acidity-influenced reactions may also play a role. Note that much of the $\mathrm{SO}_{4}$ in the Mexico City basin and outflow is neither from urban nor BB sources, so caution in the interpretation of the correlation is warranted.

\subsubsection{Relationship of OOA to $\mathrm{O}_{x}$}

Odd oxygen $\left(\mathrm{O}_{\mathrm{x}}=\mathrm{NO}_{2}+\mathrm{O}_{3}\right)$ is a photochemical product which is better conserved than $\mathrm{O}_{3}$ (since the $\mathrm{NO}+\mathrm{O}_{3}$ reaction produces $\mathrm{NO}_{2}$ which can photolyze to reform $\left.\mathrm{O}_{3}\right) . \mathrm{O}_{\mathrm{x}}$ has been shown to correlate with total OOA (the sum of SV and LV-OOA for this study) at several locations during MILAGRO (Herndon et al., 2008; Aiken et al., 2009b). The aircraft data shows similar values for the ratio of OOA to $\mathrm{O}_{\mathrm{x}}$ for RF 3 and 12. Figure 6 shows the timeseries of the PMF factors for RF3 and of $\mathrm{O}_{\mathrm{x}}$, demonstrating the strong temporal correlation. The $\Delta \mathrm{OOA} / \Delta \mathrm{O}_{\mathrm{x}}$ slopes are 147 and 153 for RF3 and RF12, respectively (see Fig. A2), and are also in the middle of the range given for Pico Tres Padres, a small mountain inside Mexico City, by Herndon et al. (2008) of $120-180 \mathrm{~g} \mathrm{sm}^{-3} \mathrm{ppm}^{-1}$ (their reported values have been converted from ambient measurement to STP of 273, 1 atm, using a factor of 1.5). Further discussion of the relationship between OOA and $\mathrm{O}_{\mathrm{x}}$ is discussed by Wood et al. (2010).

\subsection{Evolution of OA in urban-pollution dominated air}

Quantification of the $\mathrm{OA} / \triangle \mathrm{CO}, \mathrm{PMF}$ factors, and $\mathrm{O} / \mathrm{C}$ ratios allow us to characterize the evolution of bulk OA in terms
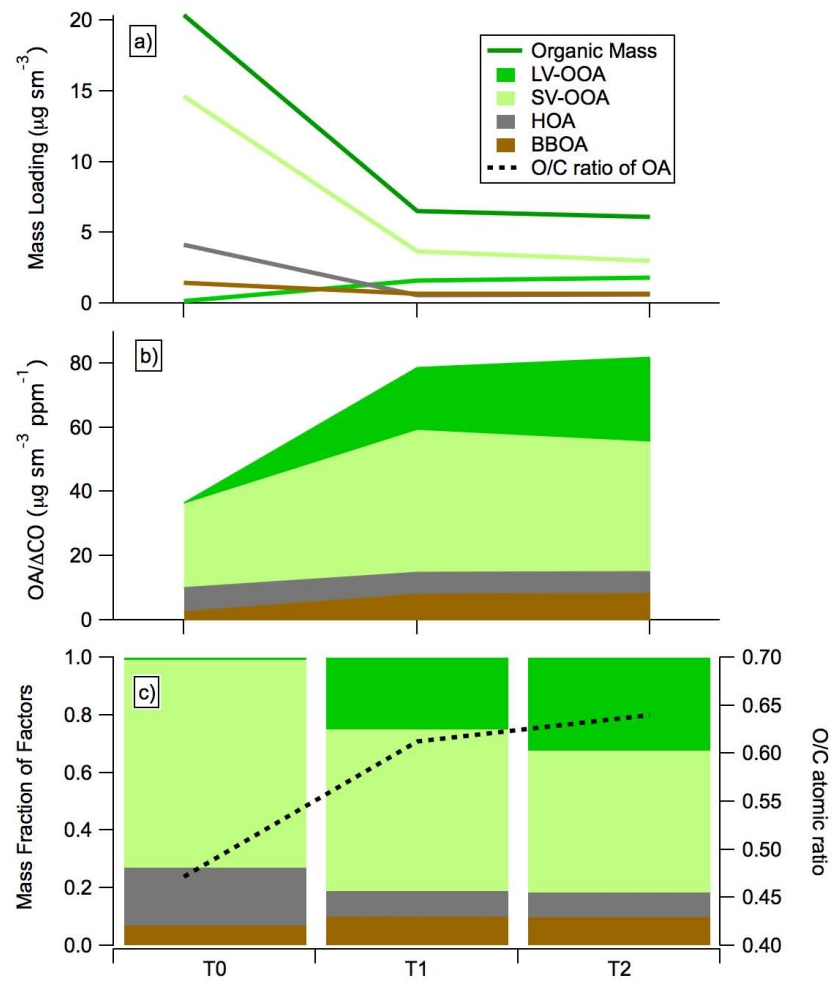

Fig. 7. (a) shows the average absolute concentration of OA and PMF factors for each flight segment in the vicinity of T0, T1, and $\mathrm{T} 2$, respectively during RF12. (b) shows the average PMF Factor/ $\triangle \mathrm{CO}$ ratio for each flight segment. (c) shows the mass fraction of each PMF factor and the mass-weighted average OA O/C atomic ratio for each flight segment.

of amount and oxidation state. This section characterizes the chemical aging of urban OA as it is transported away from Mexico City. RF12 overflights of the ground supersites at T0, $\mathrm{T} 1$, and T2 coupled with dominant wind transport to the NNE allow for an analysis in a pseudo-Lagrangian framework. The approximate distance from T0 to $\mathrm{T} 1$ is $30 \mathrm{~km}$, which corresponds to a $\sim 3 \mathrm{~h}$ transport time for the wind speeds during this day; from T0 to T2 the distance is $63 \mathrm{~km}$ or $\sim 6 \mathrm{~h}$ of transport time. Figure SI-5, http://www.atmos-chem-phys. net/10/5257/2010/acp-10-5257-2010-supplement.pdf shows the flight track and the portions of the flight that were averaged together for the data points at the T0, T1, and T2 legs of the flight. Figure 7 a shows the absolute concentration of $\mathrm{OA}$ of each factor. For all of factors except LV-OOA, there is a decrease in concentration due to dilution during advection. Figure $7 \mathrm{~b}$ shows the $\mathrm{OA} / \Delta \mathrm{CO}$ ratios in order to remove the effect of dilution and Fig. 7c shows the mass fractions of the different factors as a function of distance from the city. $\mathrm{HOA} / \triangle \mathrm{CO}$ is stable over this timescale $(7.3,6.9$, and $7.0 \mu \mathrm{g} \mathrm{sm}^{-3} \mathrm{ppmv}^{-1}$ at $\mathrm{T} 0, \mathrm{~T} 1$, and $\mathrm{T} 2$ respectively), indicating that HOA is conserved in this dataset on a timescale 
of $\sim 6 \mathrm{~h}$ of aging, at least within PMF's ability to retrieve this component. $\mathrm{BBOA} / \triangle \mathrm{CO}$ increases slightly downwind, although the interpretation of BBOA in this flight is uncertain as discussed above. SV-OOA is already the dominant factor in the city, consistent with the rapid SOA formation from urban emissions identified in previous studies. There is a clear increase in $\mathrm{OA} / \triangle \mathrm{CO}$ with distance from the city, driven by additional SOA formation. This additional SOA formation appears to level off by T2, again consistent with the fast timescale for this process identified in previous studies (de Gouw et al., 2008). Both SV-OOA and LV-OOA are approximately constant from $\mathrm{T} 1$ to $\mathrm{T} 2$, but when the ratios to $\triangle \mathrm{CO}$ are used SV-OOA decreases by approximately $10 \%$ from $\mathrm{T} 1$ to $\mathrm{T} 2$ (from 44 to $40 \mu \mathrm{g} \mathrm{sm}^{-3} \mathrm{ppmv}^{-1}$ ), potentially indicating the further processing of SV-OOA mass into LV-OOA associated mass. The most likely mechanism for this processing would be through gas-phase reactions of semivolatile species, as heterogeneous reactions were shown to be too slow to explain the observed gain of oxygen (DeCarlo et al., 2008). Also shown in Fig. 7c is the average atomic $\mathrm{O} / \mathrm{C}$ for the total aerosol sampled over each leg of the flight. A clear increase in this ratio from 0.47 to 0.64 is seen over short oxidation timescales of $\sim 6 \mathrm{~h}$ transport time. As shown here, the combination of PMF and $\mathrm{OA} / \Delta \mathrm{CO}$ analyses allows further insights than either type of analysis alone.

\subsection{Comparison of BBOA factor with WRF-FLEXPART results}

Given the good correlation of the modeled WRFFLEXPART fire impact factor (FIF) with the impact of BB emissions at T0 (Aiken et al., 2009a) and similar agreement for the dispersion of industrial $\mathrm{NO}_{2}$ and $\mathrm{SO}_{2}$ emissions by Rivera et al. (2009), it is of interest to compare this type of FIF with the calculated PMF BBOA during our flights. Figure 8 shows the comparison between the BBOA factor and the $+/-500 \mathrm{~m}$ vertically-integrated FIF for both emission scenarios. Other vertical integration scenarios showed poorer correlation and are not shown. The FIF comparison shows relatively good correlation in and around the city basin for the 12:00-20:00 LST (18:00-02:00 UTC) emission scenario, especially when considering the $10 \mathrm{~km}$ horizontal resolution of the model and the uncertainties in vertical dispersion and integration. In the far field, the BBOA and FIF have peaks of the same relative magnitude compared to the city, but they appear spatially offset, likely due to model transport errors. The different emission scenarios show quite different predictions in the city basin with the earlier emission scenario (12:00-20:00 LST) showing broader plumes which are more consistent with the BBOA observations, while the 14:0024:00 emission scenario produces a spikier FIF (smaller spatial extent of the plumes) which is less consistent with observations. Aiken et al. (2009a) concluded that the FIF with the 14:00-24:00 emission scenario produced better agreement with the observations at $\mathrm{T} 0$, which on the surface contrasts with our conclusion. However we note that ground-based observations are most sensitive to the tail end of the emissions, which are injected into the shallow nighttime boundary layer and thus lead to high concentrations at the ground in the early morning. The time when emission start may vary from day to day, and ground-based observations will be less sensitive to the emissions between 12:00-14:00 which are dispersed into a very deep boundary layer and may not be completely mixed down to the ground (Crounse et al., 2009). For the aircraft comparison, fire impacts will be very sensitive to the modeled start of the emissions since aircraft sampling in the city occurs $1-3 \mathrm{~h}$ after the start of the emissions for one scenario and $3-5 \mathrm{~h}$ for the other. The doubling of the amount of time available for smoke dispersion in the model results in large differences in the spatial character of the FIF predictions. Overall the performance of WRF-FLEXPART for MILAGRO appears to be quite good, considering the uncertainties of models and measurements, and it is highly recommended that future studies explore the use of WRFFLEXPART FIFs for the characterization of the dispersion of open fire emissions.

\subsection{Postprocessing of RF3 PMF solution for more direct source apportionment}

The factors directly output by PMF are groupings of organic species of similar chemical composition (as viewed by the fragmentation in the analysis method of the AMS), which associate with sources and processing of OA in the atmosphere. HOA and BBOA are factors more typically associated with sources of aerosol, but as discussed above, the separation of HOA and BBOA may not be perfect and may be improved with postprocessing. SV-OOA and LV-OOA are better associated with processes in the atmosphere, namely SOA formation, and OA and SOA aging, respectively. Although some OOA spectral features may be more associated with specific SOA sources such as biogenic SOA (KiendlerScharr et al., 2009; Ng et al., 2010) at present PMF-AMS spectra have not been shown to be sufficiently specific for determining SOA sources directly. For a dataset such as the one in RF3, with several strong source types and a large dynamic range of photochemical aging, postprocessing of the PMF results using external information such as source tracers is required. Although the postprocessing technique has limitations which can be further explored in other datasets, it is clear that the explicit PMF solution does not adequately report direct source apportionment, and that postprocessing will improve the attribution of OA mass to specific sources. Post processing of the PMF solution for RF3 will yield 2

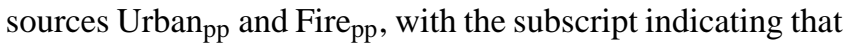
they are the source attribution from the post-processed PMF solution. 


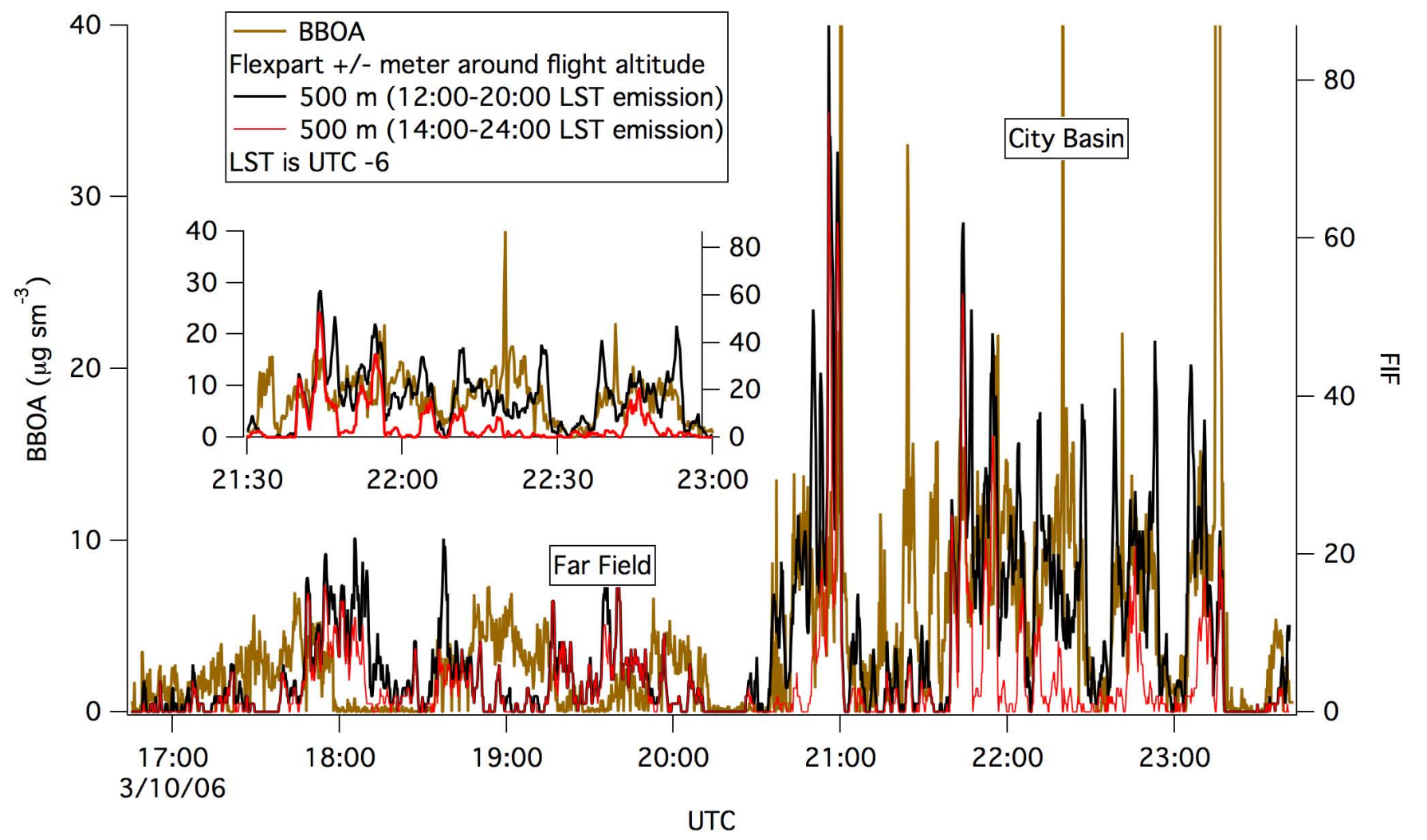

Fig. 8. Shown here is the timeseries of the BBOA factor from PMF analysis with the FIF calculated from WRF-FLEXPART modeling. The two diurnal fire emission scenarios for the $+/-500 \mathrm{~m}$ vertical integration for FIFs around the aircraft altitude are given. The inset shows a zoom of a portion of data within the MCMA basin.

\subsubsection{Attribution of HOA in RF3 to urban and BB sources}

Both RF3 and RF12 regressions show good correlation of $\mathrm{HOA}$ and $\mathrm{CO}$, and $\mathrm{HOA} / \triangle \mathrm{CO}$ within the observed range as discussed in Sect. 3.2.1 above, as shown in Fig. 4 and A2. However, it is unlikely that the same urban source would have such different $\mathrm{HOA} / \Delta \mathrm{CO}$ for the 2 different flights, and presumably the difference in the slopes of the regression is due to a portion of the HOA factor in RF3 arising from biomass burning aerosol as discussed above. In addition to excess HOA coming from biomass burning, some of the $\mathrm{CO}$ in RF3 will also be from biomass burning. Results of the $\mathrm{CO}$ apportionment between urban and fire sources (Crounse et al., 2009) suggest that approximately $30 \%$ of the $\mathrm{CO}$ in the region could be attributed to biomass burning activities during RF3. Ascribing $30 \%$ of the $\Delta \mathrm{CO}$ to fire sources and the rest of the $\Delta \mathrm{CO}$ to traffic sources we can then set the $\mathrm{HOA} / \triangle \mathrm{CO}$ ratio from $\mathrm{RF} 3$ to be equal to the observed ratio in RF12. Using these assumptions we estimate that for RF3, $51 \%$ of the PMF HOA factor is attributable to urban sources for, and we assign the other $49 \%$ to BB sources. For RF 12 all $\mathrm{HOA}$ and $\mathrm{CO}$ are assigned to urban sources.

\subsubsection{Relationship between BBOA and $\mathrm{HCN}$}

The regression between BBOA and HCN clearly shows a BBOA factor being retrieved consistently in RF3 with all regressions showing $R$ values around 0.9 (see Figs. 4 and A2), although there is significant variability in the slope of BBOA to HCN. RF12 shows little correlation between $\mathrm{BBOA}$ and $\mathrm{HCN}$ and the regression slope has a low value, consistent with the uncertainty about the origin of BBOA in RF12. During RF12, narrow plumes with elevated HCN levels were intercepted. These plumes of $\mathrm{HCN}$ were not associated with BBOA but rather with the Tula petrochemical complex, see Fig. SI-6, http://www.atmos-chem-phys. net/10/5257/2010/acp-10-5257-2010-supplement.pdf. For $\mathrm{RF} 3$ one can approximate $\mathrm{BBOA} / \triangle \mathrm{CO}$ for this factor using the measured $\mathrm{BBOA} / \triangle \mathrm{HCN}$ and MILAGRO literature values for the $\triangle \mathrm{HCN} / \triangle \mathrm{CO}$ emission ratio. Yokelson et al. (2007) report an $\Delta \mathrm{HCN} / \Delta \mathrm{CO}$ for forest fire emissions of $117(\mathrm{~mol} / \mathrm{mol})$, while Crounse et al. report $104(\mathrm{~mol} / \mathrm{mol})$. Using these values the BBOA PMF factor found in this analysis has BBOA/ $\triangle \mathrm{CO}$ of 148 or $165 \mu \mathrm{g} \mathrm{sm}^{-3} \mathrm{ppmv}^{-1}$ using the $\triangle \mathrm{HCN} / \triangle \mathrm{CO}$ from Yokelson and Crounse, respectively. These calculated values are consistent with the range of reported values of the primary $\mathrm{OA} / \Delta \mathrm{CO}$ emission ratios given 
Yokelson et al. (2007) (Fig. 3), but smaller than the ambient $\mathrm{BBOA} / \triangle \mathrm{CO}$ ratio derived from multiple linear regression in the Crounse et al. (2009) study of $211 \mu \mathrm{g} \mathrm{sm}{ }^{-3} \mathrm{ppm}^{-1}$. This analysis is consistent with some of the BBOA being apportioned by PMF into other factors with a more reduced (HOA) or more oxidized (OOA) chemical profile. As discussed above, this dataset spans a very large range of photochemical ages for BBOA, from nearly fresh emissions to BBOA advected regionally and which has undergone intense photochemistry. The variablitlity in the true BBOA spectrum cannot be fit by PMF due to the needed assumption of constant mass spectra; the postprocessing attempts to separate some mixing of chemistry and sources in the factors.

\subsubsection{Lack of influence of BB sources on SV-OOA}

As both aerosol nitrate and SV-OOA are fast secondary products of photo-oxidative processes, one expects a correlation of these factors due to similar production mechanisms and timescales. The SV-OOA/ $/ \mathrm{NO}_{3}$ ratio is quite consistent, and is driven mostly by the MCMA parts of the flights where the $\mathrm{NO}_{3}$ and SV-OOA levels have the most dynamic range (Fig. 4). Away from the city in the regional air, SVOOA/ $/ \mathrm{NO}_{3}$ increases, most likely due to evaporation of nitrate (DeCarlo et al., 2008), as this species is more volatile than SV-OOA (Huffman et al., 2009a), and potentially also to the reaction of $\mathrm{NO}_{3}$ with dust (Querol et al., 2008). Due to the consistency of this ratio across the 2 flights with very different biomass burning influence, and the lack of correlation of SV-OOA with HCN, we conclude that SV-OOA is dominated by fresh urban SOA and does not have a substantial contribution from $\mathrm{BB}$ emissions.

\subsubsection{Apportionment of LV-OOA to open BB vs. other sources}

The regression of $\mathrm{LV}-\mathrm{OOA}$ to aerosol $\mathrm{SO}_{4}$ yields different slopes for the 2 different flights (see Figs. 4 and A2). Several potential reasons for this difference exist, such as different source strengths of $\mathrm{SO}_{2}$ during the two periods, in particular for volcanic sources that are major contributors to regional $\mathrm{SO}_{2}$ and can be quite variable in time (Grutter et al., 2008; de Foy et al., 2009a). Another possible cause for changes in this ratio is differences in wet deposition during the periods, which may affect $\mathrm{LV}-\mathrm{OOA}$ and $\mathrm{SO}_{4}$ differently as the slowly reacting and less soluble $\mathrm{SO}_{2}$ is left behind in the airmass while the SOA precursors are exhausted faster, as proposed by Brock et al. (2008). The observations, however, do show roughly similar concentrations of $\mathrm{SO}_{4}$ during both flights, so an alternative explanation for the higher ratio in the first flight would be additional LV-OOA from oxidation of BBOA precursors. The magnitude of this contribution to LV-OOA can be estimated by assuming that the $\mathrm{LV}-\mathrm{OOA} / \mathrm{SO}_{4}$ ratio seen in RF12 as the base urban/regional ratio (with little biomass burning influence) is correct for this area and this time of year, and then we can estimate the impact of BB on LV-OOA for RF3 using the measured slopes. Taking the ratio of the slopes of RF12/RF3, we arrive at an estimate that only $36 \%$ of the LV-OOA measured in RF3 is due to urban/regional pollution with the remaining $64 \%$ arising from the enhanced BB during that period.

Once this postprocessing has been applied, the fraction of OA associated with BB increases from $49 \%$ to $67 \%$ above the Mexico City basin, and from $31 \%$ to $67 \%$ for regional air. The main effect of postprocessing is due to the addition of part of the LV-OOA in RF3 into Fire . $_{\text {. }}$

\subsection{Comparison to previous tracer-based source apportionment study}

This Total Least Squares (TLS) source apportionment approach used by Crounse et al. (2009) analysis is independent of the PMF results here (with the minor exception of the use of the Crounse et al. (2009) CO apportionment for our HOA postprocessing, as discussed above) and therefore it is of interest to compare its results to those from our study. Figure 9a-d show the flight time series comparison for the postprocessed urban + non-BB regional OA $\left(\right.$ Urban $\left.\mathrm{OA}_{\mathrm{pp}}\right)$ and total fire associated aerosol (Fire $\mathrm{pp}$ ) with the Crounse et al. (2009) time series of the urban and fire components. Statistics for the comparison given in figure 9 e-f indicate good agreement between the different apportionment methods with R2 larger than 0.8 in both cases and slopes between 0.8 and 1.12 for the urban + non-BB regional $\mathrm{OA}$ and fire associated OA respectively. For RF3 our results agree well with those of Crounse et al. (2009). RF3 can roughly be broken into 2 separate segments: prior to 20:30 the aircraft was sampling regionally, while afterwards it was sampling in and around the basin. The comparison is good for both segments. This is consistent with the aging of BBOA transforming some of the material into an LV-OOA type mixture on this scale. Within the city basin, the fractional contribu-

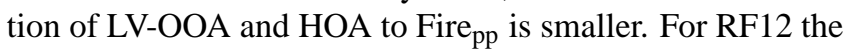
agreement is better for the urban area than for regional air, where the uncertainties are larger for both methods, as discussed above for the PMF postprocessing results, and as exemplified by Fig SI-3, http://www.atmos-chem-phys.net/10/ 5257/2010/acp-10-5257-2010-supplement.pdf for the use of tracers in regional air. Fire $\mathrm{pp}_{\mathrm{p}}$ contributes $66 \%$ of the OA in RF3 ( $\sim 50 \%$ in urban area) and $10 \%$ in RF12, while the urban + non-BB regional factor contribution is $34 \%$ and $90 \%$ for RF3 and RF12 respectively.

Overall the TLS tracer method and our PMF-based method produce a very similar picture of the contribution of OA sources to air aloft over the urban area and the Central Mexican Plateau, and the differences are probably within the uncertainties of both methods. The underlying assumption in the TLS method is that the ratios of tracer species to pollutants are constant, which, especially for urban OA, is known not to be the case. This is mostly due to strong SOA 

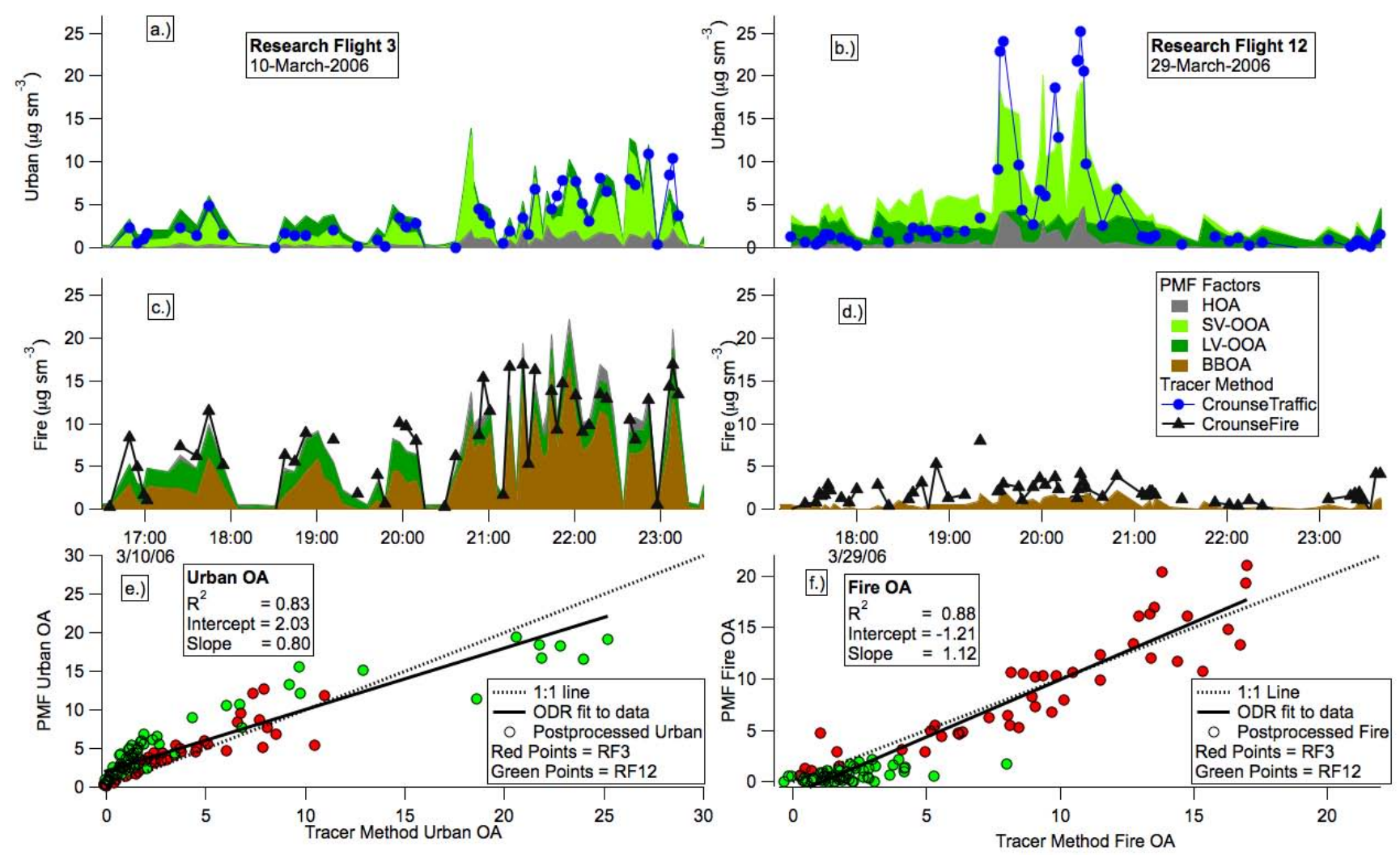

Fig. 9. (a-d) show the RF3 and RF12 comparison to the Crounse et al. (2009) study for the urban OA factor and the fire OA factor. The postprocessed PMF components contribution to urban and fire sources are the solid colors stacked on top of each other. Parts e and $f$ are scatter plots comparing the postprocessed PMF urban OA vs. Tracer method urban OA and the postprocessed PMF fire OA vs the Tracer method fire OA respectively. The points are colored by flight.

formation as photochemical age increases. Uncertainty in the PMF solution results from fitting constant MS to truly variable chemical signatures, which is addressed in an approximate manner by the postprocessing method described above.

The higher fraction of OA associated with fire sources in this aircraft dataset contrasts with lower fractions ( $\sim 15-23 \%$ averaged over the campaign, Aiken et al., 2009a) determined by many studies for the T0 supersite inside the urban area. The reasons for these differences have been discussed in detail by Aiken et al. (2009a) and include: (a) the ground concentrations are 24-hr averages, including periods of shallow boundary layer at night when ground OA concentrations from urban sources are highest, as compared to the flights which occur in the afternoon at the peak of the fire emissions; (b) the difference between surface (relevant to T0) and column-integrated concentrations (more relevant to the aircraft), with the latter being more heavily influenced by open $\mathrm{BB}$; (c) although mixing in the afternoon BL is thought to be vigorous, it may not be complete inside of the basin since many of the open BB sources are close to the urban area; e.g. Crounse et al. (2009) reported a 50\% lower relative im- pact of BB at the ground vs. aloft which is presumably due to this; (d) the potential impact of other BB sources with lower emission ratios at the ground.

\subsection{Net effect of aging and SOA formation on BBOA mass}

We can use the results of our study and that of Crounse et al. (2009) to estimate the net effect of SOA formation on OA mass from open $\mathrm{BB}$ emissions from $\sim 3 \mathrm{~h}$ to 1 day of photochemical processing. Figure 10 shows the regressions of Urban $\mathrm{OA}_{\mathrm{pp}}$ vs. $\Delta \mathrm{CO}_{\mathrm{UR}}$ and Fire $\mathrm{pp}$ vs. $\Delta \mathrm{CO}_{\mathrm{BB}}$, where the $\mathrm{OA}$ is estimated from our study and $\triangle \mathrm{CO}$ according with the Crounse et al. (2009) method. Figure 10a shows the scatter plot of Urban $\mathrm{OA}_{\mathrm{pp}} / \Delta \mathrm{CO}_{\mathrm{UR}}$, which shows similar slopes for both flights. The slope increases as $\Delta \mathrm{CO}_{\mathrm{UR}}$ decreases for more aged air, consistent with the larger fractional effect of SOA formation on urban $\mathrm{OA} / \triangle \mathrm{CO}$ as discussed above. Figure $10 \mathrm{~b}$ shows for $\mathrm{RF} 3$, that the $\mathrm{BBOA}_{\mathrm{pp}} / \triangle \mathrm{CO}_{\mathrm{BB}}$ ratio appears to be approximately constant at $210 \mu \mathrm{g} \mathrm{sm}^{-3} \mathrm{ppbv}^{-1}$, which is almost identical to the ratio of 211 determined by Crounse et al. (2009). Compared to the P-BBOA ratios of Yokelson et al. (2007) of $148 \mathrm{\mu g} \mathrm{sm}^{-3} \mathrm{ppmv}^{-1}$ and 

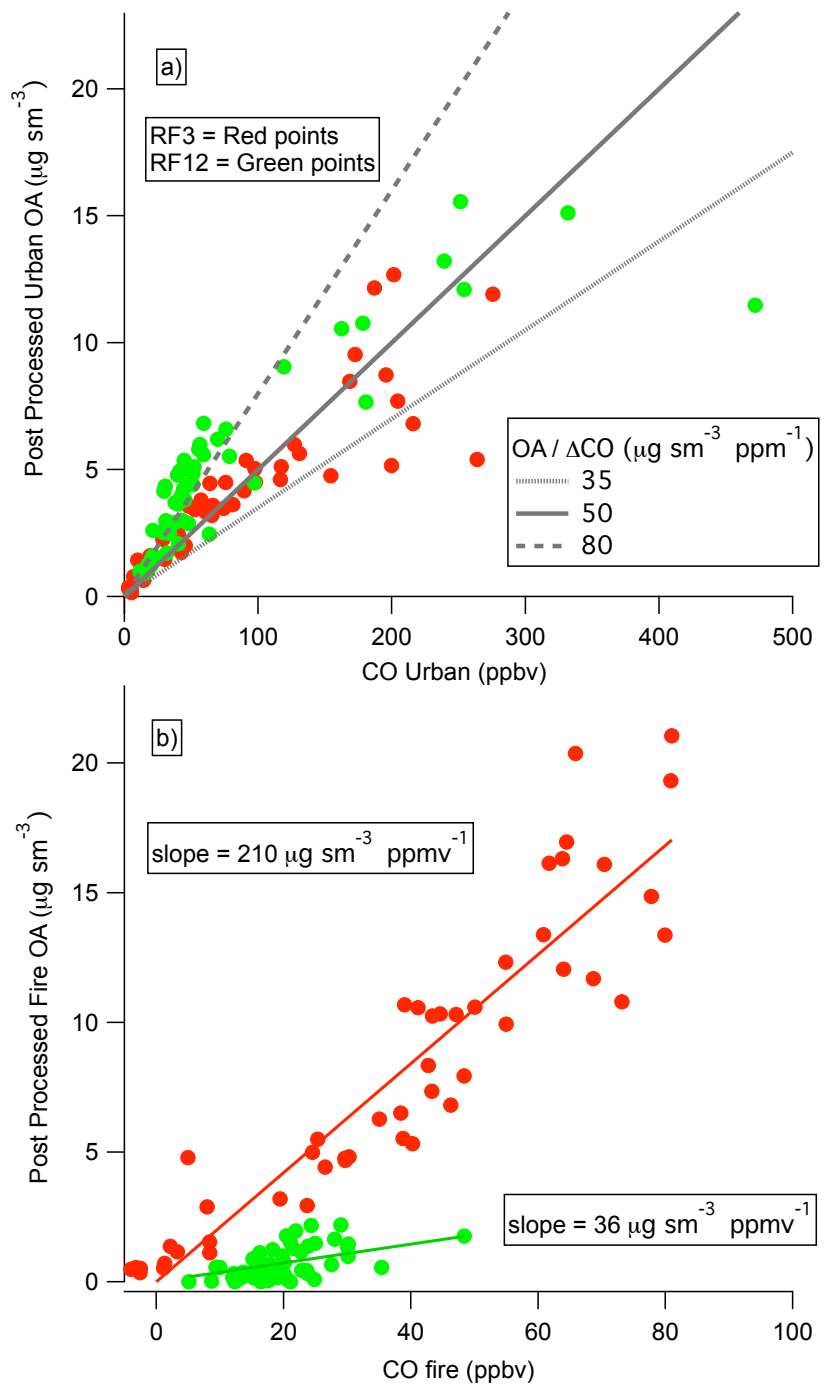

Fig. 10. Scatter plots of urban/regional OA vs. urban $\mathrm{CO}$ and fireassociated OA vs. fire-associated $\mathrm{CO}$ are shown in parts a) and b) respectively. Points are colored by flight with RF3 as red points and RF12 as green points. CO data comes from the Crounse et al. (2009) analysis. Lines of different slopes in part a) are intended to guide the eye.

the ratio for fresh plumes from DeCarlo et al. (2008) of $160 \mu \mathrm{g} \mathrm{sm}^{-3} \mathrm{ppmv}^{-1}$, this suggests a net effect of OA evaporation, aging, and SOA formation resulting in an addition of mass of $\sim 32-42 \%$ of the P-BBOA mass in several hours to a day. Yokelson et al. (2007) had estimated a doubling of $\mathrm{P}-\mathrm{BBOA} / \triangle \mathrm{CO}$ due to SOA formation (i.e. a net effect of $100 \%$ ), but such a large fractional SOA formation does not appear to be observed in this study. This is also consistent with the lack of observation of $\mathrm{BB}$ plumes at twice the $\mathrm{P}-\mathrm{BBOA} / \triangle \mathrm{CO}$ ratio (which would correspond to about $356-$ $370 \mu \mathrm{g} \mathrm{sm}^{-3} \mathrm{ppbv}^{-1}$ ) in this study. This study reinforces the conclusion from previous studies that the net effect of aging and SOA formation on BBOA mass may be quite variable

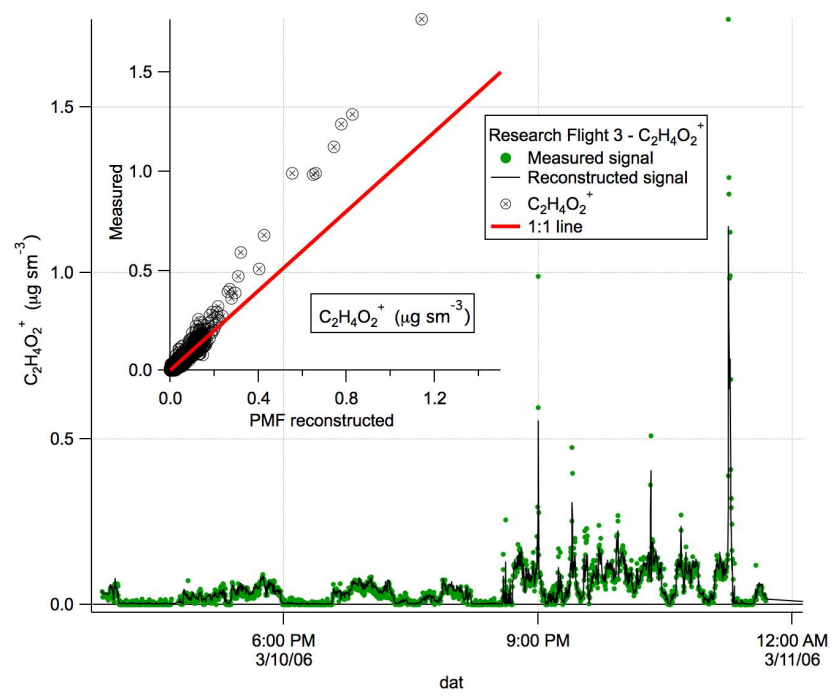

Fig. 11. This figure shows the timeseries of the measured and the PMF modeled signal for $\mathrm{C}_{2} \mathrm{H}_{4} \mathrm{O}_{2}^{+}$. A scatter plot of the measured vs. PMF modeled signal for $\mathrm{C}_{2} \mathrm{H}_{4} \mathrm{O}_{2}^{+}$is shows as part of the inset.

depending on parameters such as biomass burned, flaming vs. smoldering fraction, etc. The $\mathrm{BBOA}_{\mathrm{pp}} / \triangle \mathrm{CO}_{\mathrm{BB}}$ slope for RF12 is much lower, which may be due to the influence of local burning sources with lower emission factors.

\subsection{Apportionment of $\mathrm{C}_{2} \mathrm{H}_{4} \mathrm{O}_{2}^{+}(\mathrm{m} / z, 60)$ and reduction of its fractional signal during aging}

AMS $m / z 60$ is commonly used as a marker for BB emissions in AMS datasets, including both open burning and woodstove emissions (Schneider et al., 2006; Alfarra et al., 2007). High-resolution observations confirm that almost all the signal at this ion for ambient and source datasets is due to $\mathrm{C}_{2} \mathrm{H}_{4} \mathrm{O}_{2}^{+}$(Aiken et al., 2009b; Mohr et al., 2009). Due to the range of $\mathrm{BB}$ plume ages sampled in this study, it is of interest to see if PMF can reproduce the time series of this ion. Figure 11 shows the timeseries of the measured $\mathrm{C}_{2} \mathrm{H}_{4} \mathrm{O}_{2}^{+}$and PMF-modeled $\mathrm{C}_{2} \mathrm{H}_{4} \mathrm{O}_{2}^{+}$. The inset of Fig. 11 shows the scatter plot of measured vs. PMF modeled $\mathrm{C}_{2} \mathrm{H}_{4} \mathrm{O}_{2}^{+}$. The timeseries and scatter plot clearly show that at higher $\mathrm{C}_{2} \mathrm{H}_{4} \mathrm{O}_{2}^{+}$ concentrations corresponding to strong $\mathrm{BB}$ plumes, the modeled $\mathrm{C}_{2} \mathrm{H}_{4} \mathrm{O}_{2}^{+}$is underestimated by PMF, whereas outside strong $\mathrm{BB}$ plumes, modeled $\mathrm{C}_{2} \mathrm{H}_{4} \mathrm{O}_{2}^{+}$more closely follows the measured $\mathrm{C}_{2} \mathrm{H}_{4} \mathrm{O}_{2}^{+}$. This result is indicative of some loss of the species producing this ion as the plume dilutes and/or is photochemically processed, due to either evaporation or chemical reactions. This loss appears to be initially rapid and of the order of $30 \%$ (Fig. 11 inset) and followed by a stabilization. The possibility of evaporation is supported by the results of Huffman et al. (2009a) who showed that the species producing $m / z 60$ are among the more volatile ones in source and ambient BBOA, based on tandem thermodenuder 
+ HR-ToF-AMS studies. The possibility of chemical reaction is supported by laboratory chamber studies from Hennigan et al. (2010) who show a reduction of $m / z 60$ of about $30 \%$ after several hours of $\mathrm{OH}$ exposure. Since $\mathrm{m} / \mathrm{z} 60$ is often used as a proxy for levoglucosan and related species, the loss of $m / z, 60$ with time indicates that care must be taken to use $m / z 60$ to organics or levoglucosan/BBOA appropriate to the BBOA observed (fresh vs. aged), as otherwise BBOA concentrations could be under or overestimated.

\section{Conclusions}

The sources and processing of submicron organic aerosol above Mexico City and the Central Mexican Plateau have been characterized using data from 2 research flights during the MILAGRO campaign in March 2006. The general trends of the $\mathrm{OA} / \triangle \mathrm{CO}$ ratio for these two flights were very consistent with observations made in many other field studies. The $\mathrm{OA} / \triangle \mathrm{CO}$ ratio for $\mathrm{RF} 12$ in the absence of strong biomass burning influence shows a substantial increase in this ratio indicating rapid SOA formation, coincident with a corresponding increase in the $\mathrm{O} / \mathrm{C}$ atomic ratio of the bulk $\mathrm{OA}$. Biomass burning has high initial $\mathrm{OA} / \Delta \mathrm{CO}$ ratios and lower $\mathrm{O} / \mathrm{C}$ atomic ratios. PMF was applied to a high-massresolution organic mass spectral aircraft dataset for the first time. Two flights, representing high and low biomass burning influence were combined, and 4 factors were used to describe the dataset: HOA, BBOA, SV-OOA, and LV-OOA. BBOA was correlated with a fire impact factor derived from WRF-FLEXPART modeling, with some location offsets in the far field, most likely due to transport errors. Correlations of aerosol nitrate, sulfate, and $\mathrm{O}_{\mathrm{x}}$ with OOA confirm the dominance of SOA in the region during periods with low wildfire activities. A pseudo-Lagrangian case study of the evolution of urban OA during RF12 shows the increase in the $\mathrm{OOA} / \triangle \mathrm{CO}$ ratio and bulk $\mathrm{O} / \mathrm{C}$ ratio, and the stability of the HOA factor when accounting for dilution on the timescale of transport $(\sim 6 \mathrm{~h})$. Due to the large range of photochemical ages spanned by our aircraft study, post-processing of the PMF results was used to achieve better correspondence with source contributions rather than chemical similarity. During the high $\mathrm{BB}$ flight, $\mathrm{BBOA}_{\mathrm{pp}}$ accounted for $\sim 2 / 3$ of the total OA. In the flight with low BB activity, the BBOA retrieval was uncertain and accounted for only $\sim 10 \%$ of the OA. These results compared well with a previous independent source apportionment study based on tracer ratios. Our study confirms that the influence of BBOA was greater aloft and over regional scales than at the ground inside the city, likely due to the aircraft measurements being made aloft, where the biomass burning emissions are injected, and during the afternoons, when the fires are strongest. The net effect of BBOA evaporation, BBOA aging, and SOA formation is estimated as an addition of mass of about $\sim 32-42 \%$ of the primary BBOA. An examination of the apportionment of the
AMS BB marker $\mathrm{C}_{2} \mathrm{H}_{4} \mathrm{O}_{2}^{+}(\mathrm{m} / \mathrm{z}, 60)$ is consistent with previous results that indicate that although it is not a completely conserved tracer, at least a fraction of it persists during aging and it remains a good marker for BBOA.

\section{Appendix A}

\section{Methodology for the choice of PMF solution}

\section{A1 Choice of number of factors}

The choice of the 4-factor solution was made based on the mass spectral profiles and time series of the factors for solutions with varying numbers of factors. As mentioned previously, when the flights were run individually a satisfactory 4-factor solution was obtained for RF3, but for RF12 the 3factor solution was the most reasonable solution. A combined dataset of RF3 and RF12 was therefore run to force factor profiles to be identical. In this combined dataset, four factors should also be resolved. Table A1 provides a subjective description of the 2-8 factor solutions and reasons for choosing the 4-factor solution as a starting point from the combined RF3-RF12 dataset.

\section{A2 Variation in the 4-factor solution}

PMF was run with 50 random initial values at the start of the iterative solution procedure ("seeds") to explore the solution space for FPEAK=0. These solutions showed considerable variability, and therefore the analysis presented here will first focus on the choice of solution from the variability in the seed solutions.

Solutions from each seed were sorted into different "family" types by visual inspection of the factor mass spectra and time series (see Figs. SI7, http://www.atmos-chem-phys.net/10/5257/2010/ acp-10-5257-2010-supplement.pdf and SI-8 for typical MS and profiles for each solution type). Figure A1 shows the results of this initial sorting into family types with the solutions within each family type sorted by the $Q / Q_{\exp }$ value; low $Q / Q_{\exp }$ values indicate a better fit to the data and can be used as one criterion to choose a suitable PMF solution (Lanz et al., 2007; Ulbrich et al., 2009). Six of the 50 seed solutions (Solution type 1) converged to nearly identical solutions with the lowest value of $Q / Q_{\text {exp }}$, see Fig. A1a. Although the total range of $Q / Q_{\text {exp }}$ varied by only $\sim 1.5 \%(0.739-0.750)$ there were substantial differences across the 50 solutions.

Second, a more subjective but quantifiable approach to choosing the best solution was performed. For each of the seed solutions the 4 factors were assigned as HOA, BBOA, SV-OOA or LV-OOA based on mass spectral and time series profiles. This allows the possibility of a systematic regression analysis between the tracer and factor time series. Previous studies have shown strong correlations of SV-OOA 
Table A1. This table describes the reasons for the choice of the 4 factor PMF solution.

\begin{tabular}{lll}
\hline Number of Factors & $Q / Q_{\exp }$ & Description of solution \\
\hline 2 & 0.88 & Too few factors, 2 OOA-like factors, MS appear mixed \\
3 & 0.78 & Too few factors, $m / z$ 60 split between multiple factors, suggesting that there are not enough factors. \\
4 & 0.74 & HOA, BBOA, SV-OOA, and LV-OOA factors found \\
$5-8$ & $0.71-0.64$ & LV-OOA splitting evident. MS are not realistic with signal only at a few ions. \\
\hline
\end{tabular}

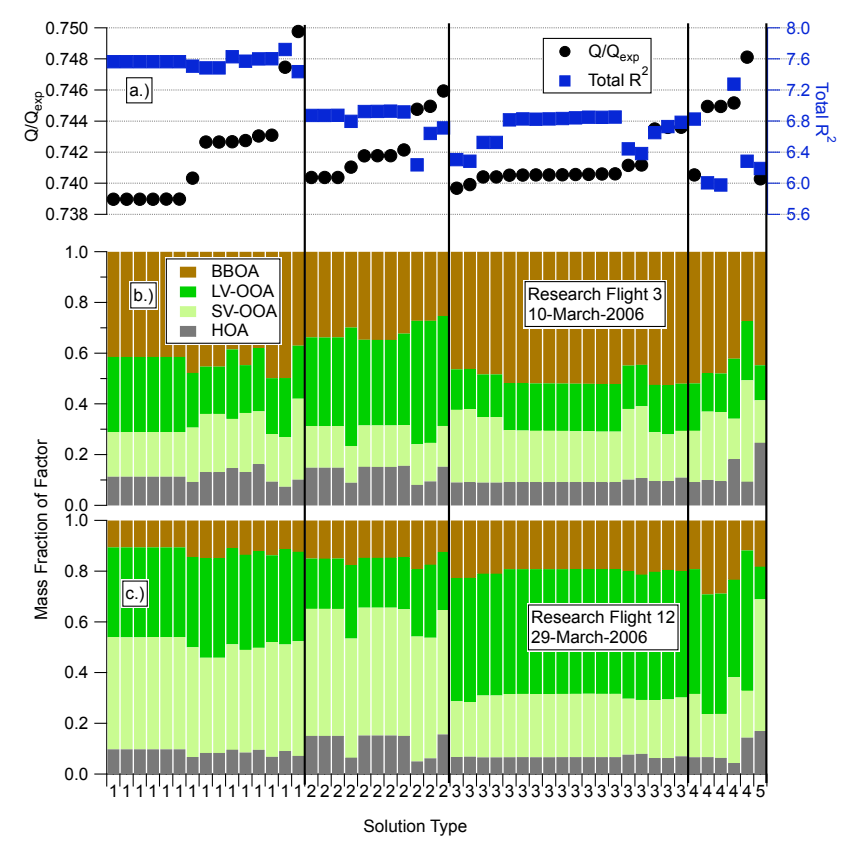

Fig. A1. (a) shows the $Q / Q_{\exp }$ and total $R^{2}$ values for the 50 seed solutions organized by solution type. Each solution type is then sorted by increasing $Q / Q_{\text {exp. (b) and (c) show the mass fractions }}$ of the different factors for each of the 50 seed solutions, and the variability in the apportionment of the seed solutions.

(OOA-2) with $\mathrm{NO}_{3}$, LV-OOA (OOA-1) with $\mathrm{SO}_{4}$ (Lanz et al., 2007; Ulbrich et al., 2009), OOA (the sum of LV-OOA and SV-OOA) with $\mathrm{O}_{\mathrm{x}}$, (Herndon et al., 2008), and HOA with CO (Zhang et al., 2005b; Lanz et al., 2007; Ulbrich et al., 2009). Biomass burning organic aerosol (BBOA) is expected to correlate with $\mathrm{HCN}$ (DeCarlo et al., 2008). For each of the 50 solutions and assigned factors, orthogonal distance regressions between the factors and specific tracers listed above were performed separately for each of the two flights. In the case of the LV-OOA to $\mathrm{SO}_{4}$ correlations, data points originating from either volcanic plumes or from the petrochemical/power plant complex in Tula were removed from the regression. These points were easy to identify due to proximity to the source and the spiky behavior of $\mathrm{SO}_{4}$ associated with these sources. This slope for each regression and the $R^{2}$ value were recorded, and all regressions from one solution were summed, yielding the total $R^{2}$ value for that particular seed solution (maximum value of 10 from 5 regressions for each of the 2 flights). Figure A1a shows the results of the total correlation for each of the solutions. Solutions with high overall correlations with appropriate tracers may also be candidates for the most reasonable PMF solution. Figure A1 shows that the solution type 1 shows the highest total correlation. Additionally, solution type 1 includes the solutions with the lowest $Q / Q_{\exp }$, indicating that both criteria point towards similar solutions as the most reasonable. It should be noted, however, that no solution is uniquely best, and the variability within a general solution group can be considered some measure of the uncertainty of the final solution. Due to the consistency of the $Q / Q_{\exp }$ results and the total $R^{2}$, the chosen PMF solution for this dataset is the lowest $Q / Q_{\exp }$ solution from type 1, the first 6 solutions in Fig. A-1. The effect of FPEAK for the four factor solution was explored with FPEAK values of \pm 1.0 in increments of 0.1 . The variability from FPEAK on these solutions was smaller than the variation amongst the solution types, as already discussed.

In addition to the total $R^{2}$ value above, additional information on the slope and regression for each factor and tracer can be examined. Figure A2 shows a scatter plot of the 50 solutions and the slope vs. the Pearson R for each of the regressions. In this figure each point is labeled as the solution type (1-5) and colored by the value of $Q / Q_{\exp }$. The final PMF solution in each panel is shown as a black circle with the value of the slope and $\mathrm{R}$ for this solution given in the panel. The chosen solution generally has correlations with tracers with Pearson $\mathrm{R}$ value greater than 0.8 , and only in the case of LV-OOA are the correlations lower for both RF3 and 12. A general observation from Fig. A2 is that for regressions with high correlation $(R>0.8)$ there is often a range spanning up to a factor of 2 in the measured slope of the regression. This indicates that the slope of a regression should also be taken into account when choosing a PMF solution and not only the correlation coefficient of a PMF factor to a tracer. 


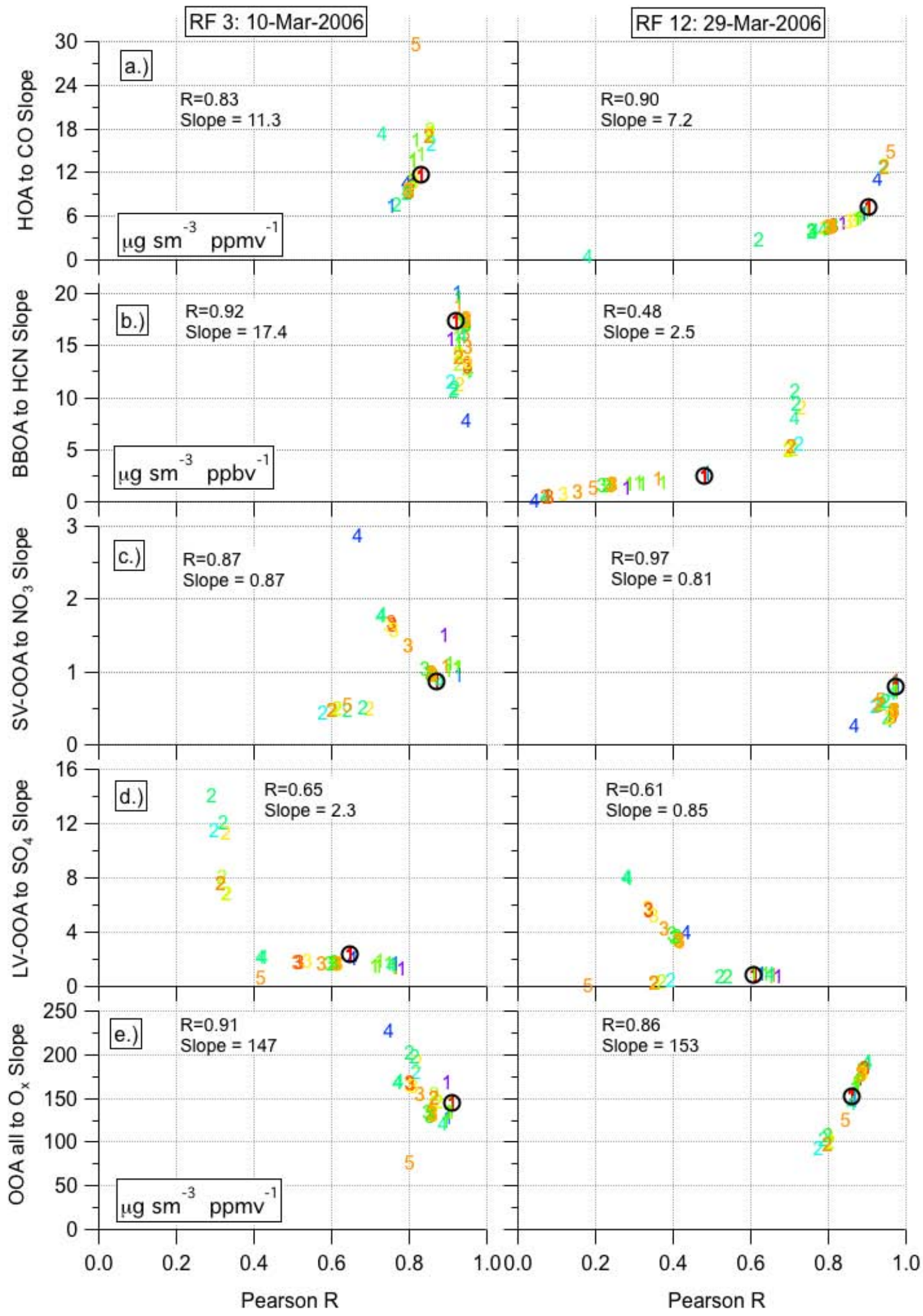

Fig. A2. The slope and Pearson R values from regressions of PMF factors vs. tracer species for the 50 seed solutions. The left column are the correlations for RF3 with the right column the same correlations for RF12. The Pearson R and slope of the chosen PMF solution is given in the caption and shown on the plot as the open black circle. Units when applicable are given in the row of the plot. 
Acknowledgements. This study was supported by NSF (ATM0449815, ATM-0513116, ATM-0810950), NSF/UCAR S05-39607, NOAA (NA08OAR4310565), and EPA STAR (RD-83216101-0 and R833747). PFD is grateful for an EPA STAR graduate fellowship (FP-91650801) and an NSF International Postdoctoral Fellowship (0701013). IMU and ACA thank NASA for graduate fellowships (NNG05GQ50H and NNG04GR06H).

Edited by: L. Molina

\section{References}

Aiken, A. C., DeCarlo, P. F., and Jimenez, J. L.: Elemental Analysis of Organic Species with Electron Ionization HighResolution Mass Spectrometry, Anal. Chem., 79(21), 83508358, doi:10.1021/ac071150w, 2007.

Aiken, A. C., DeCarlo, P. F., Kroll, J. H., Worsnop, D. R., Huffman, J. A., Docherty, K. S., Ulbrich, I. M., Mohr, C., Kimmel, J. R., Sueper, D., Sun, Y., Zhang, Q., Trimborn, A. M., Northway, M., Ziemann, P. J., Canagaratna, M. R., Onasch, T. B., Alfarra, M. R., Prevot, A. S. H., Dommen, J., Duplissy, J., Metzger, A., Baltensperger, U., and Jimenez, J. L.: O/C and OM/OC Ratios of Primary, Secondary, and Ambient Organic Aerosols with HighResolution Time-of-Flight Aerosol Mass Spectrometry, Environ. Sci. Technol., 42, 4478-4485, 2008.

Aiken, A. C., de Foy, B., Wiedinmyer, C., DeCarlo, P. F., Ulbrich, I. M., Wehrli, M. N., Szidat, S., Prevot, A. S. H., Noda, J., Wacker, L., Volkamer, R., Fortner, E., Wang, J., Laskin, A., Shutthanandan, V., Zheng, J., Zhang, R., Paredes-Miranda, G., Arnott, W. P., Molina, L. T., Sosa, G., Querol, X., and Jimenez, J. L.: Mexico City aerosol analysis during MILAGRO using high resolution aerosol mass spectrometry at the urban supersite (T0), Part 2: Analysis of the biomass burning contribution and the modern carbon fraction, Atmos. Chem. Phys. Discuss., 9, 25915-25981, 2009a,

http://www.atmos-chem-phys-discuss.net/9/25915/2009/.

Aiken, A. C., Salcedo, D., Cubison, M. J., Huffman, J. A., DeCarlo, P. F., Ulbrich, I. M., Docherty, K. S., Sueper, D., Kimmel, J. R., Worsnop, D. R., Trimborn, A., Northway, M., Stone, E. A., Schauer, J. J., Volkamer, R., Fortner, E., de Foy, B., Wang, J., Laskin, A., Shutthanandan, V., Zheng, J., Zhang, R., Gaffney, J., Marley, N. A., Paredes-Miranda, G., Arnott, W. P., Molina, L. T., Sosa, G., and Jimenez, J. L.: Mexico City aerosol analysis during MILAGRO using high resolution aerosol mass spectrometry at the urban supersite (T0) Part 1: Fine particle composition and organic source apportionment, Atmos. Chem. Phys., 9, 66336653, doi:10.5194/acp-9-6633-2009, 2009b.

Alfarra, M. R., Prevot, A. S. H., Szidat, S., Sandradewi, J., Weimer, S., Lanz, V. A., Schreiber, D., Mohr, M., and Baltensperger, U.: Identification of the Mass Spectral Signature of Organic Aerosols from Wood Burning Emissions, Environ. Sci. Technol., 41(16), 5770-5777, doi:5710.1021/es062289b, 2007.

Allan, J. D., Jimenez, J. L., Williams, P. I., Alfarra, M. R., Bower, K. N., Jayne, J. T., Coe, H., and Worsnop, D. R.: Quantitative Sampling Using an Aerodyne Aerosol Mass Spectrometer: 1. Techniques of Data Interpretation and Error Analysis, J. Geophys. Res.-Atmos., 108(D9), 4090, doi:10.1029/2002JD002358, 2003.
Allan, J. D., Williams, P. I., Morgan, W. T., Martin, C. L., Flynn, M. J., Lee, J., Nemitz, E., Phillips, G. J., Gallagher, M. W., and Coe, H.: Contributions from transport, solid fuel burning and cooking to primary organic aerosols in two UK cities, Atmos. Chem. Phys., 10, 647-668, doi:10.5194/acp-10-647-2010, 2010.

Andreae, M. O., Andreae, T. W., Annegarn, H., Beer, J., Cachier, H., le Canut, P., Elbert, W., Maenhaut, W., Salma, I., Wienhold, F. G., and Zenker, T.: Airborne studies of aerosol emissions from savanna fires in southern Africa: 2. Aerosol chemical composition, J. Geophys. Res.-Atmos., 103, 32119-32128, 1998.

Babbitt, R. E., Ward, D. E., Susott, R. S., Artaxo, P., and Kauffman, J. B.: A comparison of concurrent airborne and ground based emissions generated from biomass burning in the Amazon Basin, SCAR-B Proceedings, Transtech Editorial, Sao José dos Campos, Brazil 1997, 23-26,, 1997.

Cappa, C. D. and Jimenez, J. L.: Quantitative estimates of the volatility of ambient organic aerosol, Atmos. Chem. Phys. Discuss., 10, 1901-1938, doi:10.5194/acpd-10-1901-2010, 2010.

Chow, J. C., Watson, J. G., Edgerton, S. A., and Vega, E.: Chemical composition of PM2.5 and PM10 in Mexico City during winter 1997, Sci. Total Environ., 287, 177-201, 2002.

Crounse, J. D., DeCarlo, P. F., Blake, D. R., Emmons, L. K., Campos, T. L., Apel, E. C., Clarke, A. D., Weinheimer, A. J., McCabe, D. C., Yokelson, R. J., Jimenez, J. L., and Wennberg, P. O.: Biomass burning and urban air pollution over the Central Mexican Plateau, Atmos. Chem. Phys., 9, 4929-4944, doi:10.5194/acp-9-4929-2009, 2009.

de Foy, B., Fast, J. D., Paech, S. J., Phillips, D., Walters, J. T., Coulter, R. L., Martin, T. J., Pekour, M. S., Shaw, W. J., Kastendeuch, P. P., Marley, N. A., Retama, A., and Molina, L. T.: Basinscale wind transport during the MILAGRO field campaign and comparison to climatology using cluster analysis, Atmos. Chem. Phys., 8, 1209-1224, doi:10.5194/acp-8-1209-2008, 2008.

de Foy, B., Krotkov, N. A., Bei, N., Herndon, S. C., Huey, L. G., Martnez, A. P., Ruiz-Suarez, L. G., Wood, E. C., Zavala, M., and Molina, L. T.: Hit from both sides: tracking industrial and volcanic plumes in Mexico City with surface measurements and OMI SO2 retrievals during the MILAGRO field campaign, Atmos. Chem. Phys., 9, 9599-9617, 2009a, http://www.atmos-chem-phys.net/9/9599/2009/.

de Foy, B., Zavala, M., Bei, N., and Molina, L. T.: Evaluation of WRF mesoscale simulations and particle trajectory analysis for the MILAGRO field campaign, Atmos. Chem. Phys., 9, 44194438, 2009b, http://www.atmos-chem-phys.net/9/4419/2009/.

de Gouw, J. and Jimenez, J. L.: Organic Aerosols in the Earth's Atmosphere, Environ. Sci. Technol., 43, 7614-7618, doi:10.1021/Es9006004, 2009.

de Gouw, J. A., Middlebrook, A. M., Warneke, C., Goldan, P. D., Kuster, W. C., Roberts, J. M., Fehsenfeld, F. C., Worsnop, D. R., Canagaratna, M. R., Pszenny, A. A. P., Keene, W. C., Marchewka, M., Bertman, S. B., and Bates, T. S.: Budget of organic carbon in a polluted atmosphere: Results from the New England Air Quality Study in 2002, J. Geophys. Res.-Atmos., 110, D16305, doi:10.1029/2004JD004662, 2005.

de Gouw, J. A., Brock, C. A., Atlas, E. L., Bates, T. S., Fehsenfeld, F. C., Goldan, P. D., Holloway, J. S., Kuster, W. C., Lerner, B. M., Matthew, B. M., Middlebrook, A. M., Onasch, T. B., Peltier, R. E., Quinn, P. K., Senff, C. J., Stohl, A., Sullivan, A. P., Trainer, M., Warneke, C., Weber, R. J., and Williams, 
E. J.: Sources of Particulate Matter in the Northeastern United States: 1. Direct Emissions and Secondary Formation of Organic Matter in Urban Plumes, J. Geophys. Res., 113, D08301, doi:08310.01029/02007JD009243, 2008.

de Gouw, J. A., Welsh-Bon, D., Warneke, C., Kuster, W. C., Alexander, L., Baker, A. K., Beyersdorf, A. J., Blake, D. R., Canagaratna, M., Celada, A. T., Huey, L. G., Junkermann, W., Onasch, T. B., Salcido, A., Sjostedt, S. J., Sullivan, A. P., Tanner, D. J., Vargas, O., Weber, R. J., Worsnop, D. R., Yu, X. Y., and Zaveri, R.: Emission and chemistry of organic carbon in the gas and aerosol phase at a sub-urban site near Mexico City in March 2006 during the MILAGRO study, Atmos. Chem. Phys., 9, 3425-3442, doi:10.5194/acp-9-3425-2009, 2009.

DeCarlo, P. F., Kimmel, J. R., Trimborn, A., Northway, M. J., Jayne, J. T., Aiken, A. C., Gonin, M., Fuhrer, K., Horvath, T., Docherty, K. S., Worsnop, D. R., and Jimenez, J. L.: Field-deployable, high-resolution, time-of-flight aerosol mass spectrometer, Anal. Chem., 78, 8281-8289, 2006.

DeCarlo, P. F., Dunlea, E. J., Kimmel, J. R., Aiken, A. C., Sueper, D., Crounse, J., Wennberg, P. O., Emmons, L., Shinozuka, Y., Clarke, A., Zhou, J., Tomlinson, J., Collins, D. R., Knapp, D., Weinheimer, A. J., Montzka, D. D., Campos, T., and Jimenez, J. L.: Fast airborne aerosol size and chemistry measurements above Mexico City and Central Mexico during the MILAGRO campaign, Atmos. Chem. Phys., 8, 4027-4048, doi:10.5194/acp8-4027-2008, 2008.

Docherty, K. S., Stone, E. A., Ulbrich, I. M., DeCarlo, P. F., Snyder, D. C., Schauer, J. J., Peltier, R. E., Weber, R. J., Murphy, S. M., Seinfeld, J. H., Eatough, D. J., and Jimenez, J. L.: Apportionment of Primary and Secondary Organic Aerosols in Southern California during the 2005 Study of Organic Aerosols in Riverside (SOAR), Environ. Sci. Technol., 42, 7655-7662, 2008.

Doran, J. C., Fast, J. D., Barnard, J. C., Laskin, A., Desyaterik, Y., and Gilles, M. K.: Applications of lagrangian dispersion modeling to the analysis of changes in the specific absorption of elemental carbon, Atmos. Chem. Phys., 8, 1377-1389, doi:10.5194/acp-8-1377-2008, 2008.

Dunlea, E. J., DeCarlo, P. F., Aiken, A. C., Kimmel, J. R., Peltier, R. E., Weber, R. J., Tomlinson, J., Collins, D. R., Shinozuka, Y., McNaughton, C. S., Howell, S. G., Clarke, A. D., Emmons, L. K., Apel, E. C., Pfister, G. G., van Donkelaar, A., Martin, R. V., Millet, D. B., Heald, C. L., and Jimenez, J. L.: Evolution of Asian aerosols during transpacific transport in INTEX-B, Atmos. Chem. Phys., 9, 7257-7287, doi:10.5194/acp-9-7257-2009, 2009.

Dzepina, K., Volkamer, R. M., Madronich, S., Tulet, P., Ulbrich, I. M., Zhang, Q., Cappa, C. D., Ziemann, P. J., and Jimenez, J. L.: Evaluation of recently-proposed secondary organic aerosol models for a case study in Mexico City, Atmos. Chem. Phys., 9, 5681-5709, doi:10.5194/acp-9-5681-2009, 2009.

Emmons, L. K., Apel, E. C., Lamarque, J.-F., Hess, P. G., Avery, M., Blake, D., Brune, W., Campos, T., Crawford, J., DeCarlo, P. F., Hall, S., Heikes, B., Holloway, J., Jimenez, J. L., Knapp, D. J., Kok, G., Mena-Carrasco, M., Olson, J., O’Sullivan, D., Sachse, G., Walega, J., Weibring, P., Weinheimer, A., and Wiedinmyer, C.: Impact of Mexico City emissions on regional air quality from MOZART-4 simulations, Atmos. Chem. Phys. Discuss., 10, 3457-3498, doi:10.5194/acpd-10-3457-2010, 2010.

Fast, J., Aiken, A. C., Allan, J., Alexander, L., Campos, T., Cana- garatna, M. R., Chapman, E., DeCarlo, P. F., de Foy, B., Gaffney, J., de Gouw, J., Doran, J. C., Emmons, L., Hodzic, A., Herndon, S. C., Huey, G., Jayne, J. T., Jimenez, J. L., Kleinman, L., Kuster, W., Marley, N., Russell, L., Ochoa, C., Onasch, T. B., Pekour, M., Song, C., Ulbrich, I. M., Warneke, C., WelshBon, D., Wiedinmyer, C., Worsnop, D. R., Yu, X.-Y., and Zaveri, R.: Evaluating simulated primary anthropogenic and biomass burning organic aerosols during MILAGRO: implications for assessing treatments of secondary organic aerosols, Atmos. Chem. Phys., 9, 6191-6215, doi:10.5194/acp-9-6191-2009, 2009.

Fast, J. D., de Foy, B., Acevedo Rosas, F., Caetano, E., Carmichael, G., Emmons, L., McKenna, D., Mena, M., Skamarock, W., Tie, X., Coulter, R. L., Barnard, J. C., Wiedinmyer, C., and Madronich, S.: A meteorological overview of the MILAGRO field campaigns, Atmos. Chem. Phys., 7, 2233-2257, doi:10.5194/acp-7-2233-2007, 2007.

George, I. J., Slowik, J., and Abbatt, J. P. D.: Chemical aging of ambient organic aerosol from heterogeneous reaction with hydroxyl radicals, Geophys. Res. Lett., 35, doi:10.1029/2008GL033884, 2008.

Grieshop, A. P., Logue, J. M., Donahue, N. M., and Robinson, A. L.: Laboratory investigation of photochemical oxidation of organic aerosol from wood fires 1: measurement and simulation of organic aerosol evolution, Atmos. Chem. Phys., 9, 1263-1277, doi:10.5194/acp-9-1263-2009, 2009a.

Grieshop, A. P., Logue, J. M., Donahue, N. M., and Robinson, A. L.: Laboratory investigation of photochemical oxidation of organic aerosol from wood fires 1: measurement and simulation of organic aerosol evolution, Atmos. Chem. Phys., 9, 1263-1277, doi:10.5194/acp-9-1263-2009, 2009 b.

Grutter, M., Basaldud, R., Rivera, C., Harig, R., Junkerman, W., Caetano, E., and Delgado-Granados, H.: $\mathrm{SO}_{2}$ emissions from Popocatépetl volcano: emission rates and plume imaging using optical remote sensing techniques, Atmos. Chem. Phys., 8, 6655-6663, doi:10.5194/acp-8-6655-2008, 2008.

Hallquist, M., Wenger, J. C., Baltensperger, U., Rudich, Y., Simpson, D., Claeys, M., Dommen, J., Donahue, N. M., George, C., Goldstein, A. H., Hamilton, J. F., Herrmann, H., Hoffmann, T., Iinuma, Y., Jang, M., Jenkin, M. E., Jimenez, J. L., Kiendler-Scharr, A., Maenhaut, W., McFiggans, G., Mentel, Th. F., Monod, A., Prévôt, A. S. H., Seinfeld, J. H., Surratt, J. D., Szmigielski, R., and Wildt, J.: The formation, properties and impact of secondary organic aerosol: current and emerging issues, Atmos. Chem. Phys., 9, 5155-5236, doi:10.5194/acp-95155-2009, 2009.

Heald, C. L., Goldstein, A. H., Allan, J. D., Aiken, A. C., Apel, E., Atlas, E. L., Baker, A. K., Bates, T. S., Beyersdorf, A. J., Blake, D. R., Campos, T., Coe, H., Crounse, J. D., DeCarlo, P. F., de Gouw, J. A., Dunlea, E. J., Flocke, F. M., Fried, A., Goldan, P., Griffin, R. J., Herndon, S. C., Holloway, J. S., Holzinger, R., Jimenez, J. L., Junkermann, W., Kuster, W. C., Lewis, A. C., Meinardi, S., Millet, D. B., Onasch, T., Polidori, A., Quinn, P. K., Riemer, D. D., Roberts, J. M., Salcedo, D., Sive, B., Swanson, A. L., Talbot, R., Warneke, C., Weber, R. J., Weibring, P., Wennberg, P. O., Worsnop, D. R., Wittig, A. E., Zhang, R., Zheng, J., and Zheng, W.: Total observed organic carbon (TOOC) in the atmosphere: a synthesis of North American observations, Atmos. Chem. Phys., 8, 2007-2025, doi:10.5194/acp-82007-2008, 2008. 
Hecobian, A., Liu, Z., Hennigan, C., et al.: Comparison of the Chemical and Physical Evolution and Characteristics of 495 Biomass Burning Plumes Intercepted by the NASA DC-8 Aircraft during the ARCTAS/CARB-2008 Field Campaign, Atmos. Chem. Phys. Discuss., in prep., 2010.

Hennigan, C. J., Sullivan, A. P., Collett, J. L. J., and Robinson, A. L.: Levoglucosan stability in biomass burning particles exposed to hydroxyl radicals, Geophys. Res. Lett., 37, L09806, doi:10.1029/2010GL043088, 2010.

Hodzic, A., Jimenez, J. L., Madronich, S., Aiken, A. C., Bessagnet, B., Curci, G., Fast, J., Lamarque, J.-F., Onasch, T. B., Roux, G., Schauer, J. J., Stone, E. A., and Ulbrich, I. M.: Modeling organic aerosols during MILAGRO: importance of biogenic secondary organic aerosols, Atmos. Chem. Phys., 9, 6949-6981, doi:10.5194/acp-9-6949-2009, 2009.

Hodzic, A., Jimenez, J. L., Madronich, S., Canagaratna, M. R., DeCarlo, P. F., Kleinman, L., and Fast., J.: Potential contribution of semi-volatile and intermediate volatility primary organic compounds to secondary organic aerosol in the Mexico City region., Atmos. Chem. Phys. Discuss., 10, 657-710, doi:610.5194/acpd5110-5657-2010, 2010.

Huffman, J. A., Docherty, K. S., Aiken, A. C., Cubison, M. J., U1brich, I. M., DeCarlo, P. F., Sueper, D., Jayne, J. T., Worsnop, D. R., Ziemann, P. J., and Jimenez, J. L.: Chemically-resolved aerosol volatility measurements from two megacity field studies, Atmos. Chem. Phys., 9, 7161-7182, 2009a,

http://www.atmos-chem-phys.net/9/7161/2009/.

Huffman, J. A., Docherty, K. S., Mohr, C., Cubison, M. J., Ulbrich, I. M., Ziemann, P. J., Onasch, T. B., and Jimenez, J. L.: Chemically-Resolved Volatility Measurements of Organic Aerosol from Different Sources, Environ Sci Technol, 43, 14, 5351-5357, doi:10.1021/es803539d, 2009b.

Jimenez, J. L., Jayne, J. T., Shi, Q., Kolb, C. E., Worsnop, D. R., Yourshaw, I., Seinfeld, J. H., Flagan, R. C., Zhang, X. F., Smith, K. A., Morris, J. W., and Davidovits, P. Ambient Aerosol Sampling using the Aerodyne Aerosol Mass Spectrometer, J. Geophys. Res.-Atmos., 108, 8425, doi:8410.1029/2001JD001213, 2003.

Jimenez, J. L., Canagaratna, M. R., Donahue, N. M., Prevot, A. S. H., Zhang, Q., Kroll, J. H., DeCarlo, P. F., Allan, J. D., Coe, H., Ng, N. L., Aiken, A. C., Docherty, K., Ulbrich, I. M., Grieshop, A. P., Robinson, A. L., Duplissy, J., Smith, J. D., Wilson, K. R., Lanz, V. A., Hueglin, C., Sun, Y. L., Tian, J., Laaksonen, A., Raatikainen, T., Rautiainen, J., Vaattovaara, P., Ehn, M., Kulmala, M., Tomlinson, J. M., Collins, D. R., Cubison, M. J., Dunlea, E. J., Huffman, J. A., Onasch, T. B., Alfarra, M. R., Williams, P. I., Bower, K., Kondo, Y., Schneider, J., Drewnick, F., Borrmann, S., Weimer, S., Demerjian, K., Salcedo, D., Cottrell, L., Griffin, R., Takami, A., Miyoshi, T., Hatakeyama, S., Shimono, A., Sun, J. Y., Zhang, Y. M., Dzepina, K., Kimmel, J. R., Sueper, D., Jayne, J. T., Herndon, S. C., Trimborn, A. M., Williams, L. R., Wood, E. C., Kolb, C. E., Baltensperger, U., and Worsnop, D. R.: Evolution of Organic Aerosols in the Atmosphere, Science, 326, 1525-1529, doi:1510.1126/science.1180353, 2009.

Kiendler-Scharr, A., Zhang, Q., Hohaus, T., Kleist, E., Mensah, A., Mentel, T. F., Spindler, C., Uerlings, R., Tillmann, R., and Wildt, J.: Aerosol Mass Spectrometric Features of Biogenic SOA: Observations from a Plant Chamber and in Rural Atmospheric Environments, Environ. Sci. Technol., 43, 8166-8172, doi:10.1021/es901420b, 2009.

Kleinman, L. I., Daum, P. H., Lee, Y. N., Senum, G. I., Springston, S. R., Wang, J., Berkowitz, C., Hubbe, J., Zaveri, R. A., Brechtel, F. J., Jayne, J., Onasch, T. B., and Worsnop, D.:: Aircraft observations of aerosol composition and ageing in New England and Mid-Atlantic States during the summer 2002 New England Air Quality Study field campaign, J Geophys Res-Atmos, 112, D09310, doi:09310.01029/02006JD007786 2007.

Kleinman, L. I., Springston, S. R., Daum, P. H., Lee, Y.-N., Nunnermacker, L. J., Senum, G. I., Wang, J., Weinstein-Lloyd, J., Alexander, M. L., Hubbe, J., Ortega, J., Canagaratna, M. R., and Jayne, J.: The time evolution of aerosol composition over the Mexico City plateau, Atmos. Chem. Phys., 8, 1559-1575, doi:10.5194/acp-8-1559-2008, 2008.

Kroll, J. H., Smith, J. D., Che, D. L., Kessler, S. H., Worsnop, D. R., and Wilson, K. R.: Measurement of Fragmentation and Functionalization pathways in the heterogeneous oxidation of oxidized organic aerosol, Phys. Chem. Chem. Phys., 11, 8005-8014, doi:8010.1039/b905289e, 2009.

Lanz, V. A., Alfarra, M. R., Baltensperger, U., Buchmann, B., Hueglin, C., and Prevot, A. S. H.: Source apportionment of submicron organic aerosols at an urban site by factor analytical modelling of aerosol mass spectra, Atmos. Chem. Phys., 7, 15031522, 2007, http://www.atmos-chem-phys.net/7/1503/2007/.

Lanz, V. A., Alfarra, M. R., Baltensperger, U., Buchmann, B., Hueglin, C., Szidat, S., Wehrli, M. N., Wacker, L., Weimer, S., Caseiro, A., Puxbaum, H., and Prevot, A. S. H.: Source attribution of submicron organic aerosols during wintertime inversions by advanced factor analysis of aerosol mass spectra, Environ. Sci. Technol., 42, 214-220, doi:10.1021/es0707207, 2008.

Lanz, V. A., Prévôt, A. S. H., Alfarra, M. R., Mohr, C., DeCarlo, P. F., Weimer, S., Gianini, M. F. D., Hueglin, C., Schneider, J., Favez, O., D’Anna, B., George, C., and Baltensperger, U.: Characterization of aerosol chemical composition by aerosol mass spectrometry in Central Europe: an overview, Atmos. Chem. Phys. Discuss., 9, 24985-25021, doi:10.5194/acpd-924985-2009, 2009.

Liousse, C., Devaux, C., Dulac, F., and Cachier, H.: Aging of Savanna Biomass Burning Aerosols - Consequences on thier Optical Properties, J. Atmos. Chem., 22, 1-17, 1995.

Marley, N. A., Gaffney, J. S., Tackett, M., Sturchio, N. C., Heraty, L., Martinez, N., Hardy, K. D., Marchany-Rivera, A., Guilderson, T., MacMillan, A., and Steelman, K.: The impact of biogenic carbon sources on aerosol absorption in Mexico City, Atmos. Chem. Phys., 9, 1537-1549, 2009,

http://www.atmos-chem-phys.net/9/1537/2009/.

Mohr, C., Huffman, J. A., Cubison, M. J., Aiken, A. C., Docherty, K. S., Kimmel, J. R., Ulbricht, I. M., Hannigan, M., and Jimenez, J. L.: Characterization of Primary Organic Aerosol Emissions from Meat Cooking, Trash Burning, and Motor Vehicles with High-Resolution Aerosol Mass Spectrometry and Comparison with Ambient and Chamber Observations, Environ. Sci. Technol., 43, 2443-2449, doi:10.1021/Es8011518, 2009.

Molina, L. T., Kolb, C. E., de Foy, B., Lamb, B. K., Brune, W. H., Jimenez, J. L., Ramos-Villegas, R., Sarmiento, J., ParamoFigueroa, V. H., Cardenas, B., Gutierrez-Avedoy, V., and Molina, M. J.: Air quality in North America's most populous city overview of the MCMA-2003 campaign, Atmos. Chem. Phys., 7, 2447-2473, 2007, 
http://www.atmos-chem-phys.net/7/2447/2007/.

Molina, L. T., Madronich, S., Gaffney, J. S., Apel, E., de Foy, B., Fast, J., Ferrare, R., Herndon, S., Jimenez, J. L., Lamb, B., Osornio-Vargas, A. R., Russell, P., Schauer, J. J., Stevens, P. S., and Zavala, M.: An overview of the MILAGRO 2006 campaign: Mexico City emissions and their transport and transformation, Atmos. Chem. Phys. Discuss., 10, 7819-7983, doi:10.5194/acpd-10-7819-2010, 2010.

Nemitz, E., Jimenez, J. L., Huffman, J. A., Canagaratna, M. R., Worsnop, D. R., and Guenther, A. B.: An eddy-covariance system for the measurement of surface/atmosphere exchange fluxes of submicron aerosol chemical species - first application above an urban area, Aerosol Sci. Tech., 42, 636-657, 2008.

Ng, N. L., Canagaratna, M. R., Zhang, Q., Jimenez, J. L., Tian, J., Ulbrich, I. M., Kroll, J. H., Docherty, K. S., Chhabra, P. S., Bahreini, R., Murphy, S. M., Seinfeld, J. H., Hildebrandt, L., Donahue, N. M., DeCarlo, P. F., Lanz, V. A., Prvt, A. S. H., Dinar, E., Rudich, Y., and Worsnop, D. R.: Organic aerosol components observed in Northern Hemispheric datasets from Aerosol Mass Spectrometry, Atmos. Chem. Phys., 10, 46254641, doi:10.5194/acp-10-4625-2010, 2010.

Paatero, P.: User's guide for positive matrix factorization programs PMF2.EXE and PMF3.EXE University of Helsinki, Finland, 2007.

Peltier, R. E., Sullivan, A. P., Weber, R. J., Brock, C. A., Wollny, A. G., Holloway, J. S., de Gouw, J. A., and Warneke, C.: Fine aerosol bulk composition measured on WP-3D research aircraft in vicinity of the Northeastern United States - results from NEAQS, Atmos. Chem. Phys., 7, 3231-3247, doi:10.5194/acp7-3231-2007, 2007.

Querol, X., Pey, J., Minguillón, M. C., Pérez, N., Alastuey, A., Viana, M., Moreno, T., Bernabé, R. M., Blanco, S., Cárdenas, B., Vega, E., Sosa, G., Escalona, S., Ruiz, H., and Artíñano, B.: PM speciation and sources in Mexico during the MILAGRO-2006 Campaign, Atmos. Chem. Phys., 8, 111-128, doi:10.5194/acp8-111-2008, 2008.

Reid, J. S., Koppmann, R., Eck, T. F., and Eleuterio, D. P.: A review of biomass burning emissions part II: intensive physical properties of biomass burning particles, Atmos. Chem. Phys., 5, 799825, doi:10.5194/acp-5-799-2005, 2005.

Robinson, A. L., Donahue, N. M., Shrivastava, M. K., Weitkamp, E. A., Sage, A. M., Grieshop, A. P., Lane, T. E., Pierce, J. R., and Pandis, S. N.: Rethinking organic aerosols: Semivolatile emissions and photochemical aging, Science, 315, 1259-1262, 2007.

Salcedo, D., Onasch, T. B., Dzepina, K., Canagaratna, M. R., Zhang, Q., Huffman, J. A., DeCarlo, P. F., Jayne, J. T., Mortimer, P., Worsnop, D. R., Kolb, C. E., Johnson, K. S., Zuberi, B., Marr, L. C., Volkamer, R., Molina, L. T., Molina, M. J., Cardenas, B., Bernabé, R. M., Márquez, C., Gaffney, J. S., Marley, N. A., Laskin, A., Shutthanandan, V., Xie, Y., Brune, W., Lesher, R., Shirley, T., and Jimenez, J. L.: Characterization of ambient aerosols in Mexico City during the MCMA-2003 campaign with Aerosol Mass Spectrometry: results from the CENICA Supersite, Atmos. Chem. Phys., 6, 925-946, doi:10.5194/acp-6-9252006, 2006.

Schauer, J. J., Rogge, W. F., Hildemann, L. M., Mazurek, M. A., and Cass, G. R.: Source apportionment of airborne particulate matter using organic compounds as tracers, Atmos. Environ., 30, 3837-3855, 1996.
Schneider, J., Weimer, S., Drewnick, F., Borrmann, S., Helas, G., Gwaze, P., Schmid, O., Andreae, M. O., and Kirchner, U.: Mass spectrometric analysis and aerodynamic properties of various types of combustion-related aerosol particles, Int. J. Mass Spectrom., 258, 37-49, 2006.

Shrivastava, M. K., Lipsky, E. M., Stanier, C. O., and Robinson, A. L.: Modeling semivolatile organic aerosol mass emissions from combustion systems, Environ. Sci. Technol., 40, 26712677, 2006.

Stohl, A., Forster, C., Frank, A., Seibert, P., and Wotawa, G.: Technical note: The Lagrangian particle dispersion model FLEXPART version 6.2, Atmos. Chem. Phys., 5, 2461-2474, 2005, http://www.atmos-chem-phys.net/5/2461/2005/.

Stone, E. A., Snyder, D. C., Sheesley, R. J., Sullivan, A. P., Weber, R. J., and Schauer, J. J.: Source apportionment of fine organic aerosol in Mexico City during the MILAGRO Experiment 2006, Atmos. Chem. Phys., 8, 1249-1259, 2008, http://www.atmos-chem-phys.net/8/1249/2008/.

Takegawa, N., Miyakawa, T., Kondo, Y., Blake, D. R., Kanaya, Y., Koike, M., Fukuda, M., Komazaki, Y., Miyazaki, Y., Shimono, A., and Takeuchi, T.: Evolution of submicron organic aerosol in polluted air exported from Tokyo, Geophys. Res. Lett., 33, L15814, doi:15810.11029/12006GL025815, 2006.

Tsimpidi, A. P., Karydis, V. A., Zavala, M., Lei, W., Molina, L., Ulbrich, I. M., Jimenez, J. L., and Pandis, S. N.: Evaluation of the volatility basis-set approach for the simulation of organic aerosol formation in the Mexico City metropolitan area, Atmos. Chem. Phys., 10, 525-546, doi:10.5194/acp-10-525-2010, 2010.

Ulbrich, I. M., Canagaratna, M. R., Zhang, Q., Worsnop, D. R., and Jimenez, J. L.: Interpretation of organic components from Positive Matrix Factorization of aerosol mass spectrometric data, Atmos. Chem. Phys., 9, 2891-2918, doi:10.5194/acp-9-2891-2009, 2009.

Vega, E., Reyes, E., Ruiz, H., Garcia, J., Sanchez, G., MartinezVilla, G., and Gonzalez, U.: Analysis of PM2.5 and $\mathrm{PM}_{10}$ in the atmosphere of Mexico City during 2000-2002, J. Air Waste Manage., 54, 786-798, 2004.

Volkamer, R., Jimenez, J. L., San Martini, F., Dzepina, K., Zhang, Q., Salcedo, D., Molina, L. T., Worsnop, D. R., and Molina, M. J.: Secondary organic aerosol formation from anthropogenic air pollution: Rapid and higher than expected, Geophys. Res. Lett., 33, L17811, doi:10.1029/2006GL026899., 2006.

Wiedinmyer, C., Quayle, B., Geron, C., Belote, A., McKenzie, D., Zhang, X. Y., O'Neill, S., and Wynne, K. K.: Estimating emissions from fires in North America for air quality modeling, Atmos. Environ., 40, 3419-3432, 2006.

Wood, E. C., Canagaratna, M. R., Herndon, S. C., Kroll, J. H., Onasch, T. B., Kolb, C. E., Worsnop, D. R., Knighton, W. B., Seila, R., Zavala, M., Molina, L. T., DeCarlo, P. F., Jimenez, J. L., Weinheimer, A. J., Knapp, D. J., Jobson, B. T., Stutz, J., Kuster, W. C., and Williams, E. J.: Investigation of the correlation between odd oxygen and secondary organic aerosol in Mexico City and Houston, Atmos. Chem. Phys. Discuss., 10, 35473604, doi:10.5194/acpd-10-3547-2010, 2010.

Yokelson, R. J., Urbanski, S. P., Atlas, E. L., Toohey, D. W., Alvarado, E. C., Crounse, J. D., Wennberg, P. O., Fisher, M. E., Wold, C. E., Campos, T. L., Adachi, K., Buseck, P. R., and Hao, W. M.: Emissions from forest fires near Mexico City, Atmos. Chem. Phys., 7, 5569-5584, doi:10.5194/acp-7-5569-2007, 
2007.

Yokelson, R. J., Crounse, J. D., DeCarlo, P. F., Karl, T., Urbanski, S., Atlas, E., Campos, T., Shinozuka, Y., Kapustin, V., Clarke, A. D., Weinheimer, A., Knapp, D. J., Montzka, D. D., Holloway, J., Weibring, P., Flocke, F., Zheng, W., Toohey, D., Wennberg, P. O., Wiedinmyer, C., Mauldin, L., Fried, A., Richter, D., Walega, J., Jimenez, J. L., Adachi, K., Buseck, P. R., Hall, S. R., and Shetter, R.: Emissions from biomass burning in the Yucatan, Atmos. Chem. Phys., 9, 5785-5812, doi:10.5194/acp-9-5785-2009, 2009.

Zavala, M., Herndon, S. C., Wood, E. C., Onasch, T. B., Knighton, W. B., Marr, L. C., Kolb, C. E., and Molina, L. T.: Evaluation of mobile emissions contributions to Mexico City's emissions inventory using on-road and cross-road emission measurements and ambient data, Atmos. Chem. Phys., 9, 6305-6317, doi:10.5194/acp-9-6305-2009, 2009.

Zhang, K. M. and Wexler, A. S.: Evolution of particle number distribution near roadways - Part I: analysis of aerosol dynamics and its implications for engine emission measurement, Atmos. Environ., 38, 6643-6653, 2004.

Zhang, K. M., Wexler, A. S., Zhu, Y. F., et al.: Evolution of particle number distribution near roadways. Part II: the 'road-to-ambient' process, Atmos. Environ., 38, 6655-6665, 2004.
Zhang, K. M., Wexler, A. S., Zhu, Y. F., Hinds, W. C., and Sioutas, C.: Deconvolution and Quantification of Primary and Oxygenated Organic Aerosols Based on Aerosol Mass Spectrometry. Part 1: Development and Validation of the Method., Environ. Sci. Technol., 39, 4938-4952, doi:4910.1021/es0485681, 2005a.

Zhang, Q., Worsnop, D. R., Canagaratna, M. R., and Jimenez, J. L.: Hydrocarbon-like and oxygenated organic aerosols in Pittsburgh: insights into sources and processes of organic aerosols, Atmos. Chem. Phys., 5, 3289-3311, 2005b, http://www.atmos-chem-phys.net/5/3289/2005/.

Zhang, Q., Jimenez, J. L., Canagaratna, M. R., Allan, J. D., Coe, H., Ulbrich, I., Alfarra, M. R., Takami, A., Middlebrook, A. M., Sun, Y. L., Dzepina, K., Dunlea, E., Docherty, K., DeCarlo, P. F., Salcedo, D., Onasch, T., Jayne, J. T., Miyoshi, T., Shimono, A., Hatakeyama, S., Takegawa, N., Kondo, Y., Schneider, J., Drewnick, F., Borrmann, S., Weimer, S., Demerjian, K., Williams, P., Bower, K., Bahreini, R., Cottrell, L., Griffin, R. J., Rautiainen, J., Sun, J. Y., Zhang, Y. M., and Worsnop, D. R.: Ubiquity and dominance of oxygenated species in organic aerosols in anthropogenically-influenced Northern Hemisphere midlatitudes, Geophys Res Lett, 34, L13801, doi:13810.11029/12007GL029979, 2007. 